Article

\title{
Assessment of Permian Zubers as the Host Rock for Deep Geological Disposal
}

\section{Leszek Lankof 10}

Department of Renewable Energy and Environmental Research, Mineral and Energy Economy Research Institute of the Polish Academy of Sciences, J. Wybickiego 7A, 31-261 Krakow, Poland; lankof@min-pan.krakow.pl

Received: 9 March 2020; Accepted: 21 April 2020; Published: 3 May 2020

\begin{abstract}
Together with renewable energy sources, nuclear power represents an important contribution to a sustainable energy mix in many countries and has an important impact on sustainable development. Nuclear energy production is also a source of high-level radioactive waste (HLW) and spent nuclear fuel (SNF), which require special concern. Disposal in deep geological formations is one of the solutions for the long-term management of HLW and SNF. It requires the development of a concept ensuring long-term safe isolation of waste and its validation applying the safety case methodology, which is a formal compilation of evidence, analyses and arguments that quantify and justify a claim that the repository will be safe. The results of laboratory testing of a potential repository host rock are an important component of the evidence that helps in the safety assessment of the deep geological disposal concept. This paper presents results of research focused on the physical, geomechanical and sorption properties of the Brown and Red Zuber unit rocks from the Kłodawa Salt Mine in Poland, which together with rock salt are an important component of Polish salt domes. The Brown and Red Zubers are typical evaporite lithostratigraphic units for the Polish part of the Zechstein Basin. They consist of halite (15-85\%) and water-insoluble minerals, such as anhydrite, clay minerals, carbonates, quartz and feldspar, which occurred in varying proportions in the tested samples. The properties of the zuber rocks have been compared with those of rock salt, which is considered a suitable host rock for deep geological disposal of radioactive waste.
\end{abstract}

Keywords: zuber rock; rock salt; radioactive waste; deep geological disposal; radionuclide sorption; geomechanical properties; sustainable development

\section{Introduction}

The deep geological disposal of high-level radioactive waste (HLW) and spent nuclear fuel (SNF), ensuring its long-term isolation from the environment and groundwater, relies on interdisciplinary scientific and technical issues. The majority of the HLW and SNF comes from controlled energy production during the process of nuclear fission of heavy elements in nuclear power plants. Nuclear power represents a crucial contribution to the energy mix in many countries and has an important impact on sustainable development [1-3]. At the end of the last century, the share of electricity production from nuclear energy reached its maximum, which was about $17.9 \%$ in 1996 [4]. Currently there are 443 nuclear power reactors in the world in 30 countries. Their installed capacity is around 391 GWe and the share of nuclear power plants in global electricity production is about 10\% [5]. Interest in nuclear power remains strong in many regions, particularly in the developing world. Taking into account population growth, rising electricity consumption, climate change, security of energy supply and the price volatility of other fuels, one may expect an important role of nuclear energy in the energy mix in the longer run [6]. According to the latest research it is rather unclear how nuclear energy will contribute to global human well-being as part of sustainable development [7]. 
The extensive production of nuclear power plants generates significant amounts of radioactive waste among which SNF and HLW are the most radiotoxic. SNF is a product of the nuclear reactors operation and its composition depends on the nuclear fuel burn-up. The main part of SNF (about 95\%) consists of ${ }^{238} \mathrm{U}$. The remaining part (4-5\%) is a mixture of actinides and nuclear fission products of ${ }^{235} \mathrm{U}$ and ${ }^{239} \mathrm{Pu}$ isotopes, some of which have high radiation and long half-lives, in the millions of years. HLW is mainly a product of SNF reprocessing with high concentrations of both short and long-lived alpha, beta and gamma emitters [8]. After recovering uranium and plutonium from SNF, solutions containing fission products and actinides are solidified in the calcination process and then vitrified with borosilicate glass and stored in steel containers [9-11].

Radioactive waste management depends on the fuel cycle type applied in production of nuclear energy. SNF is initially stored for at least five years in wet storage facilities located at the power plants. Then it is delivered to a reprocessing plant or to an interim storage facility $[10,12,13]$. SNF and HLW require interim storage for about 50 years to lower the radiation level and temperature on the surface of the containers to meet the safety requirements in terms of the protection of people and the environment during the disposal facility operational and post-closure period. One of the commonly accepted disposal options is deep geological disposal at depths between $250 \mathrm{~m}$ and $1000 \mathrm{~m}$ for mined repositories [14,15]. In theory and practice, geologic isolation of radioactive waste is a safe, environmentally sound and permanent solution [16]. Currently, several countries producing nuclear energy assume deep geological disposal as an official policy [17].

The first research on the disposal of radioactive waste in deep geological formations began in the United States in the 1960s at the Salt Mine in Lyon, Kansas [18], and in Germany in 1965 in the underground research laboratory at the Asse Salt Mine [19]. In addition to rock salt, also crystalline rocks, clays and tuffs were investigated as a host rock for underground repositories [20-22]. Many underground research laboratories have been built in all countries intending deep geological disposal of HLW and SNF. In situ tests in bedded rock salt and in salt domes were conducted in underground laboratories in France, Germany and in the United States [23,24]. Due to its physicochemical and geomechanical properties, rock salt deposits were also considered as an appropriate host rock for the underground storage of natural gas, hydrogen or compressed air [25-27], as well as also for location of underground neutrino detectors [28,29].

Many years of in situ and laboratory tests have confirmed the suitability of rock salt as a host rock for an underground radioactive waste repository. The first and only deep geological disposal facility for now, the Waste Isolation Pilot Plant in the rock salt Salado Formation (Nevada, USA), obtained the permit for disposal of transuranic waste on the basis of a safety case presented in an 80,000 pages WIPP Compliance Certification Application (CCA) to the Environmental Protection Agency [30].

In connection with the plans for constructing a nuclear power plant in Poland, this paper reports on an investigation that was carried out regarding site selection for the deep geological disposal of SNF and HLW. The site selection study included the analysis of archival geological data in terms of rock structure size, as well as their geological structure and hydrogeological conditions. The analysis allowed for the initial selection of sites within igneous and metamorphic rocks, clayey rock formations as well as bedded rock salt and dome rock salt structures. Then detailed radioactive waste disposal criteria were developed on the basis of IAEA recommendations, taking into account local geological conditions, the adopted disposal concept and the applicable regulations. The developed criteria allowed to select the three salt domes of Damasławek, Łanięta and Kłodawa in Central Poland and the clay rock formation in the Jarocin-Pogorzela region for deep geological repositories [31]. Mainly due to hydrogeological and surface conditions (protected nature reserve areas), pre-selected sites within igneous and metamorphic rocks were classified for further possible research.

The selected salt domes consist of evaporites of four Zechstein cyclothems, namely PZ1-PZ4. Within older cyclothems, rock salts dominate. Anhydrite, carbonates, shales and potash salts are also found in smaller amounts. Within the younger cyclothems PZ3 and PZ4, in addition to rock salts, 
anhydrites, carbonates and potash salts, a large share is zuber rocks, i.e., rocks containing $15-85 \%$ halite and minerals such as anhydrite, clay minerals, carbonates quartz and feldspar.

Within the PZ3 cyclothem, the Brown Zuber (Na3t) was distinguished as a lithostratigraphic unit of the Gwda Formation [32-34] and within the PZ3 cyclothem the Red Zuber (Na4t) as a lithostratigraphic unit of the Korytnica Formation [32,33,35].

Analysis of the geological structure of the selected salt domes has shown that at an optimal depth for SNF and HLW disposal, in addition to rock salt, zuber rocks are very common. The idea of deep geological disposal in these salt domes [36,37], taking the amount of waste generated by planned nuclear power plants into account, indicated the need to include zuber rocks in the design concept and to carry out preliminary tests on the samples of these rocks.

Zuber rocks have been the subject of mineralogical, stratigraphic and tectonic studies [32-35], which helped to determine the stratigraphic position of these units within the PZ3 and PZ4 cyclothems of the Polish Zechstein basin. Further mineralogical and geochemical research $[38,39]$ were aimed to determine the genesis and subsequent evolution of these rocks. Similar lithostratigraphic units known as Tonmittelsalz and Tonbrockensalz were identified in the Gorleben salt dome in Germany. Mineralogical-geochemical investigations of these rocks carried out on samples taken from a deep borehole in the Gorleben salt dome have shown some similarities to the equivalent zuber beds of the Polish Zechstein basin [40].

This article presents the results of the research concerning the physical, geomechanical and sorption properties of the Brown and Red Zuber rocks from the Kłodawa Salt Mine in Poland, and its comparison to the properties of rock salt. The research was conducted at the Mineral and Energy Economy Research Institute, in co-operation with the University of Technology (AGH), the Chemkop Research and Development Centre for Mining of Chemical Raw Materials, the Silesian University and Warsaw University.

\section{Materials and Methods}

The Brown and Red Zuber rocks have not been tested as a mineral resource or in respect of their potential use for construction of underground repositories of SNF and HLW. The results of the research on these rocks presented below, with the comparison to the salt rock properties, represent the first attempt toward a comprehensive evaluation of zuber rocks as the host for the deep geological disposal of heat-generating radioactive waste.

The research was carried out on core samples, taken from the Brown and Red Zuber units in the Kłodawa Salt Mine.

The research was carried out in two phases. In the first phase (on behalf of the National Atomic Energy Agency in 1999-2001), zuber samples with a water-insoluble minerals content amounting to ca. $20-30 \%$ were selected for the laboratory tests. The comparative material consisted of the samples collected from the units of Older Halite (Na2) and the Youngest Halite (Na4a). The aim of the research was to determine the mineralogical composition, loss of mass and fracture propagation rate at increased temperatures, physical properties (porosity, density, permeability, gas content), sorption properties and mechanical properties of the zuber rocks.

During the second phase (under Grant No. 5T12B01425) the scope of the research was similar. However, the gas content tests were replaced by an extended scope of geomechanical tests. The tests were conducted on samples showing a higher variability in water-insoluble minerals content.

In the first phase of the research, cores of the Brown Zuber unit were taken from the SW gallery III at a depth of $600 \mathrm{~m}$ below surface and cores of the Red Zuber unit were taken in the vicinity of the Barbara Shaft and in the $S$ gallery (12), at depths of $600 \mathrm{~m}$ and $450 \mathrm{~m}$ below surface, respectively. A total of 60 samples of the Brown Zuber unit rocks and 31 samples of the Red Zuber unit rocks were cut out of the cores, in the form of cylinders of $90 \mathrm{~mm}$ and $50 \mathrm{~mm}$ in height and of $90 \mathrm{~mm}$ and $110 \mathrm{~mm}$ in diameter. Rock salt (PZ2 and PZ4) samples for comparative testing from were taken from galleries at a depth of $630 \mathrm{~m}$ below surface. In the second phase of the research, the Brown Zuber cores were 
taken in the SW gallery III and NE gallery III and the Red Zuber cores were taken in the west transport gallery at a depth of $600 \mathrm{~m}$ below surface. A total of 132 samples of the Brown Zuber and 100 samples of the Red Zuber were cut out of the cores in the form of cylinders with similar dimensions as in the first phase. Samples for each tests were then prepared from cylindrical core fragments. Sampling locations are presented in Figure 1.

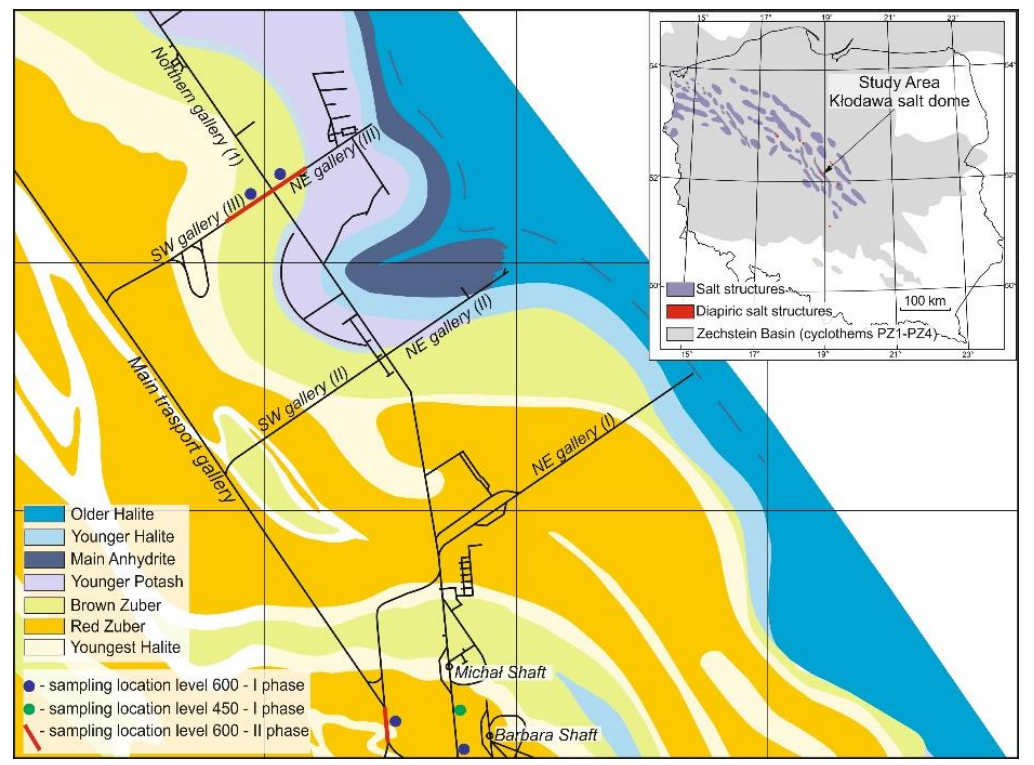

Figure 1. Study area and sampling locations in the Kłodawa Salt Mine on the background of the local geological structure (according to $[33,41]$ ).

The Red Zuber is one of the youngest lithostratigraphic units of the fourth Zechstein cyclothem (PZ4), and the Brown Zuber lithostratigraphic unit was deposited during the third cyclothem (PZ3) in the gradually shallowing Zechstein basin. Both the Brown and the Red Zubers are units of significant thickness within the salt structures occurring in the Central Poland region. Figure 2 shows the general lithostratigraphic column of the Zechstein deposits in Central Poland and examples of the core samples.
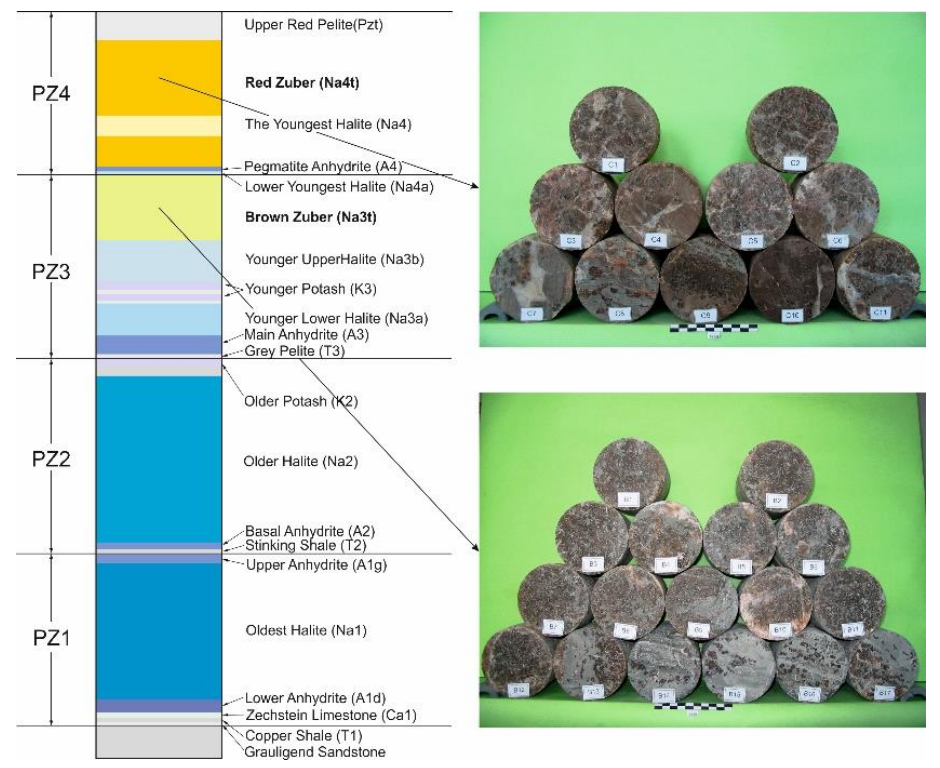

Figure 2. Example of core samples and the stratigraphic profile of the Zechstein deposits in the Central Poland region. 
The article presents selected results on the mineral composition, loss of mass and thermal expansion, sorption of radionuclides and geomechanical properties of zuber rocks.

In order to determine the mineral composition of the Brown and Red Zuber unit samples, microscopic observations of thin sections were carried out using Polmi A and Nikon 120 microscopes. Chemical microanalysis was also carried out using a CAMECA SX 100 electron probe micro analyzer. Independently, Energy Dispersive X-ray microanalysis with the Scanning Electron Microscope Jeol 540 was carried out.

To determine the amount of water-insoluble minerals content, samples were weighed and then dissolved in water. Halite dissolution was carried out until the reaction with 0.1 molar $\mathrm{AgNO}_{3}$ solution disappeared. Then the water-insoluble minerals were dried and weighed again. The phase composition of the water-insoluble minerals was determined using a PHILIPS PW 3710 X-ray diffractometer with a cobalt tube providing monochromatic radiation.

Adsorption of the radioactive isotopes was tested by static method on granulated samples with grain sizes of $2-5 \mathrm{~mm}$. Samples of $100 \mathrm{~g}$ were mixed with $80 \mathrm{~cm}^{3}$ of saturated brine containing ${ }^{90} \mathrm{SrCl}_{2}$ and ${ }^{90} \mathrm{YCl}_{3}$. The activity of solution was $24.5 \mathrm{MBq} / \mathrm{dm}^{3}\left(12.25 \mathrm{MBq} / \mathrm{dm}^{3}\right.$ for each isotope). Solution containing ${ }^{90} \mathrm{SrCl}_{2}$ and ${ }^{90} \mathrm{YCl}_{3}$ were placed in a shaker, and at specified time intervals a sample of $2 \mathrm{~cm}^{3}$ of solution was collected and centrifuged. Then, using a Geiger-Muller counter with a mica-window detector, the $\beta$-decay frequency was measured within the centrifuged brine. After measurement, samples were poured back into the solution. A similar method was applied to study Europium isotopes sorption. In this case, the tested solution contained approximately $83 \%$ of ${ }^{152} \mathrm{Eu}$ and $17 \%$ of ${ }^{154} \mathrm{Eu}$ in a saturated brine. The activity of solution was $12.2 \mathrm{MBq} / \mathrm{dm}^{3}$. Since Eu isotopes emit $\gamma$ radiation, a scintillation counter with $\mathrm{NaJ}$ and thallium as the detection material was used to measure the radiation in the brine samples. All counting frequency measurements were referred to the counting frequency of the ${ }^{90} \mathrm{Sr}+{ }^{90} \mathrm{Y}$ and ${ }^{152,154}$ Eu reference sources.

Before strength testing, samples were subjected to nondestructive testing, applying ultrasonic waves. The purpose of this test was to assess the samples' heterogeneity and elastic properties (dynamic modulus of elasticity and Poisson's ratio) by measuring the velocity of the compressional, shear and surface waves. Wave velocity measurements were conducted using an ultrasonic detector with a UMT-11 digital processor and transmitter-receiver transducer pair having a nominal frequency of $1 \mathrm{MHz}$.

Deformation and strength experiments included two types of tests: tests at a constant stress rate and tests at a constant strain rate. Triaxial strength tests with a constant strain rate were carried out in the MTS-815 press with a pressure cell and a TestStar 2 electronic load control system. The constant strain rate was $1 \times 10^{-4} \mathrm{~s}^{-1}$ or $1 \times 10^{-5} \mathrm{~s}^{-1}$ and the confining pressure was held constant at $5 \mathrm{MPa}$. During the strength tests, axial and lateral strains were monitored and the volumetric strain was calculated automatically. Strength tests in the triaxial stress state allowed to determine the maximum differential compressive stress, strain modulus E, Poisson's ratio, critical axial deformation and critical circumferential deformation.

Triaxial compression experiments at constant stress rate conditions were carried out on cylindrical samples of approx. $44 \mathrm{~mm}$ in diameter and $88 \mathrm{~mm}$ in height. The samples were placed in the pressure cell and axially loaded using a VEB WPH Leipzig hydraulic press. Confining pressure was controlled using an oil pump. First, the sample was loaded equally to reach the assumed confining pressure, and then the axial stress was increased constantly at a rate of $0.1 \mathrm{MPa} \cdot \mathrm{s}^{-1}$. The purpose of these experiments was to determine the values of the elasto-plastic deformations and the strength parameters, i.e., the maximum stresses and deformations at sample failure.

Triaxial creep tests were carried out in PeChem-3B machines with a triaxial pressure cell on cylindrical samples of $44.0 \mathrm{~mm}$ in diameter and a slenderness ratio of $\lambda=2$. The samples were placed in flexible silane covers resistant to high temperatures. Initially they were loaded hydrostatically at a constant stress rate of $0.005 \mathrm{MPa} / \mathrm{s}$, followed by axial stress up to the specified stress value. Total displacements were measured with dial indicator gauges of $0.001 \mathrm{~mm}$ accuracy. Creep tests at 
elevated temperatures were carried out in triaxial pressure cells equipped with resistance heating bands in which samples were heated first to the specified temperature and then loaded. Tests were carried out at axial stress from $12.5 \mathrm{MPa}$ to $25 \mathrm{MPa}$ and the confining pressure was 2 or $5 \mathrm{MPa}$. The differential stress ranged between 7.5 and $20.0 \mathrm{MPa}$. The minimum test duration was scheduled for about 5 months. In fact, tests lasted from 55 to 889 days. The lower limit results from the failure of one sample during the test. The majority of the triaxial creep tests were carried out in several stages at different stress and temperature conditions. The initial conditions for all tests were similar.

Relaxation experiments consisted of loading the sample in a relatively short time (about $1 \mathrm{~h}$ ) up to $30 \mathrm{MPa}$ of the axial stress at a confining pressure of $5 \mathrm{MPa}$ with simultaneous measurement of creep deformation. Then, by reducing the axial stress, deformation was held at a constant level to determine the stress at which the creep process disappears and to determine the stress drop rate.

The geomechanical research methods presented above are in accordance with the International Society for Rock Mechanics recommendations and procedures for determining the strength parameters and creep characteristics of rock [42-44]. Specimens for the strength and rheological tests are presented in Figures A1-A4.

Various sampling methods applied in the first and second phases of the research resulted in essential difference in respect of the distribution of water-insoluble minerals content in the collected test material. Respective comparisons are presented in Figures 3 and 4, showing the empirical distribution of the water insoluble minerals content (histograms) and the matching probability distribution.

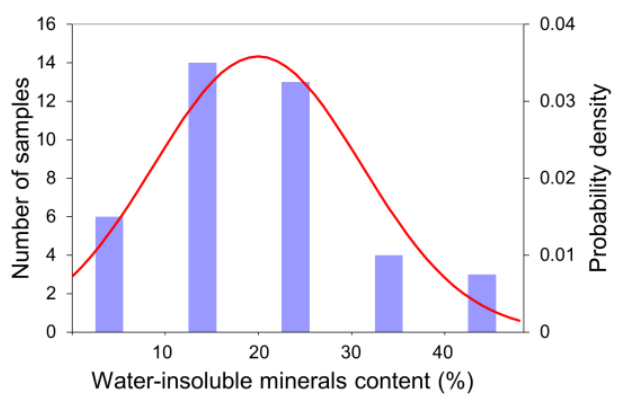

(a)

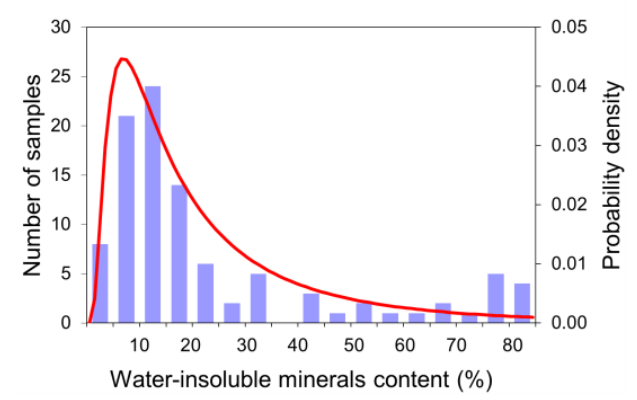

(b)

Figure 3. Distribution of the water-insoluble minerals content distribution in the Brown Zuber unit samples taken in the first (a) and the second (b) phase of the research.

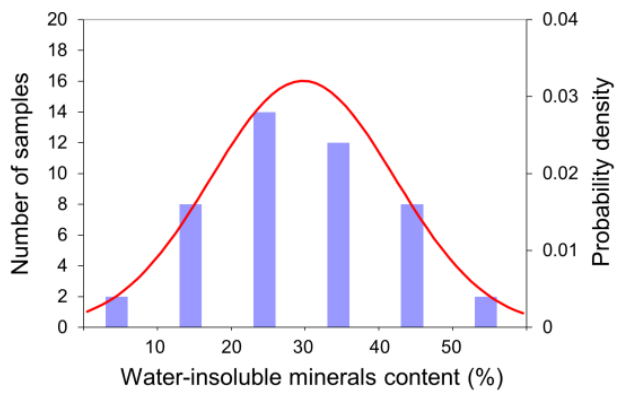

(a)

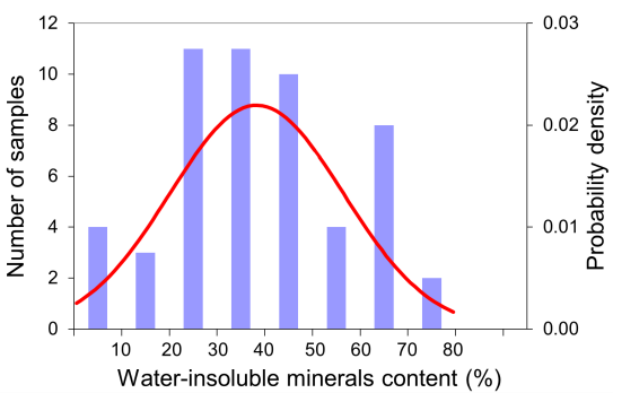

(b)

Figure 4. Distribution of the water-insoluble minerals content distribution in the Red Zuber unit samples taken in the first (a) and the second (b) phase of the research.

In three cases concerning the water-insoluble minerals content distribution, satisfactory results were obtained by normal distribution matching. However, in the case of the Brown Zuber unit sample tests conducted in the second phase (Figure 3b), the best match was obtained by inverse Gauss 
distribution. When analyzing the results, one should notice the different ranges of the water-insoluble minerals content in the samples taken in the two research phases.

\section{Results}

\subsection{Mineral Composition}

The Brown and Red Zuber lithostratigraphic units are typical for the Polish part of the Zechstein basin and they consist mainly of halite and water-insoluble minerals, such as anhydrite, clay minerals, carbonates, quartz and feldspar, which occur in varying proportions.

Halite is mainly found in the form of large, often deformed crystals (Figure 5a). Locally it occurs in the form of smaller idiomorphic crystals (Figure 5b). There are gas-liquid inclusions in the halite crystals, which are frequently irregularly distributed (Figure 5c). It may indicate that a substantial part of the crystals was formed as a result of the recrystallization and deformation of the primary halite crystals.

Anhydrite was found in various forms. The most common is a fine-crystalline anhydrite often mixed with other minerals, such as clay minerals or calcite, and larger secondary anhydrite crystallizing in fractures (Figure 5d). Clay minerals occur mainly in the form of clay-anhydrite and clay-quartz aggregates (Figure 5e). The most common minerals within this group are chlorites and illites, which occur in varying proportions. Research carried out by [45] confirm the dominance of magnesium and iron chlorites and micas, mainly illite and muscovite. The presence of expansive clay minerals of the smectite group was not noted. In many tested samples, carbonates and gypsum were also identified. Carbonates occur both in halite (Figure 5f) mainly as idiomorphic crystals and in the fine-grained anhydrite-clay matrix. Occurrence of secondary gypsum also indicates the presence of water that allows the recrystallization of the anhydrite. Gypsum was identified within the fine-crystalline matrix as well as in the single crystals within the halite. Quartz identified in thin sections occurs both in its detrital form, which indicates that it may be associated with the original sedimentation conditions in the Zechstein basin and as a secondary idiomorphic quartz (Figure 5g). Quartz is often accompanied by plagioclase occurring mainly in the Red Zuber unit rocks (Figure $5 \mathrm{~h}$ ).
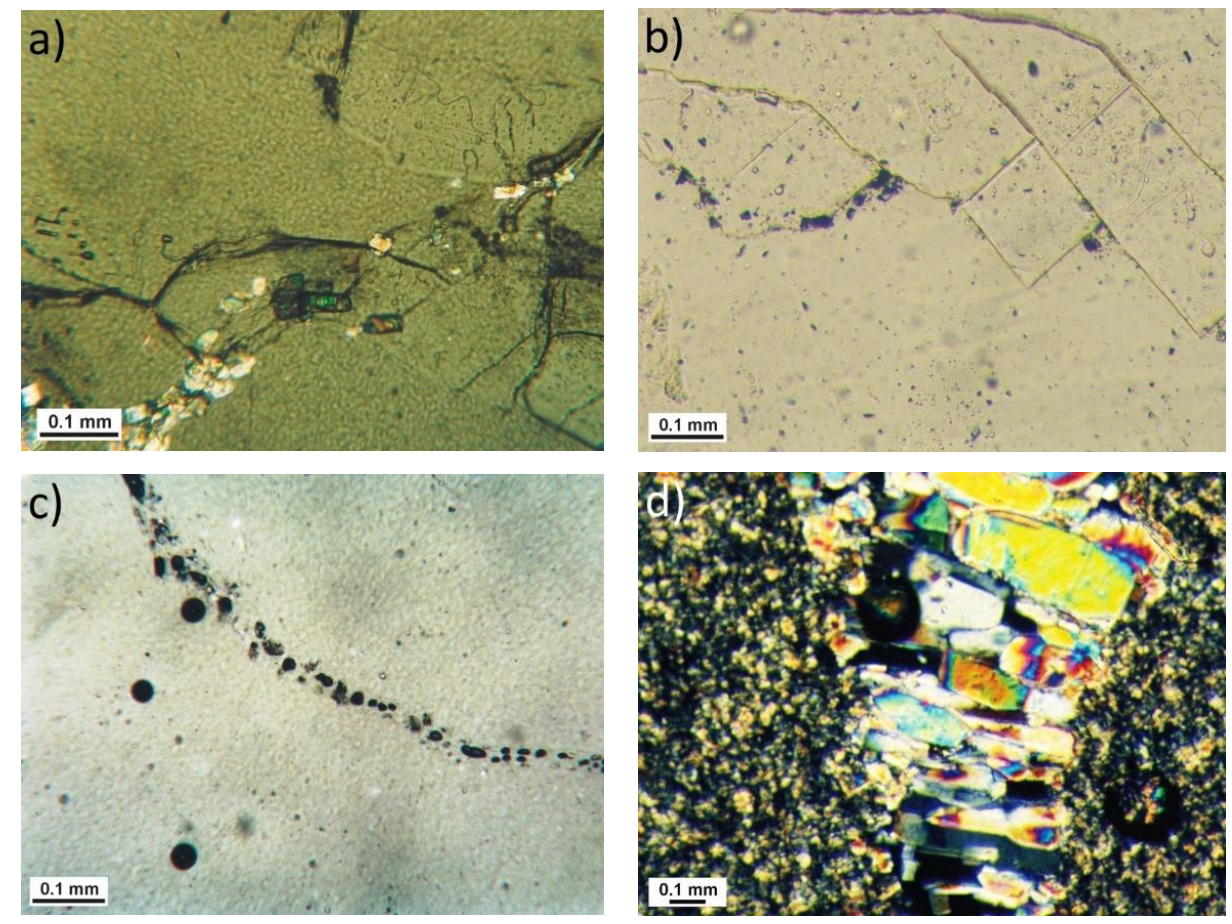

Figure 5. Cont. 

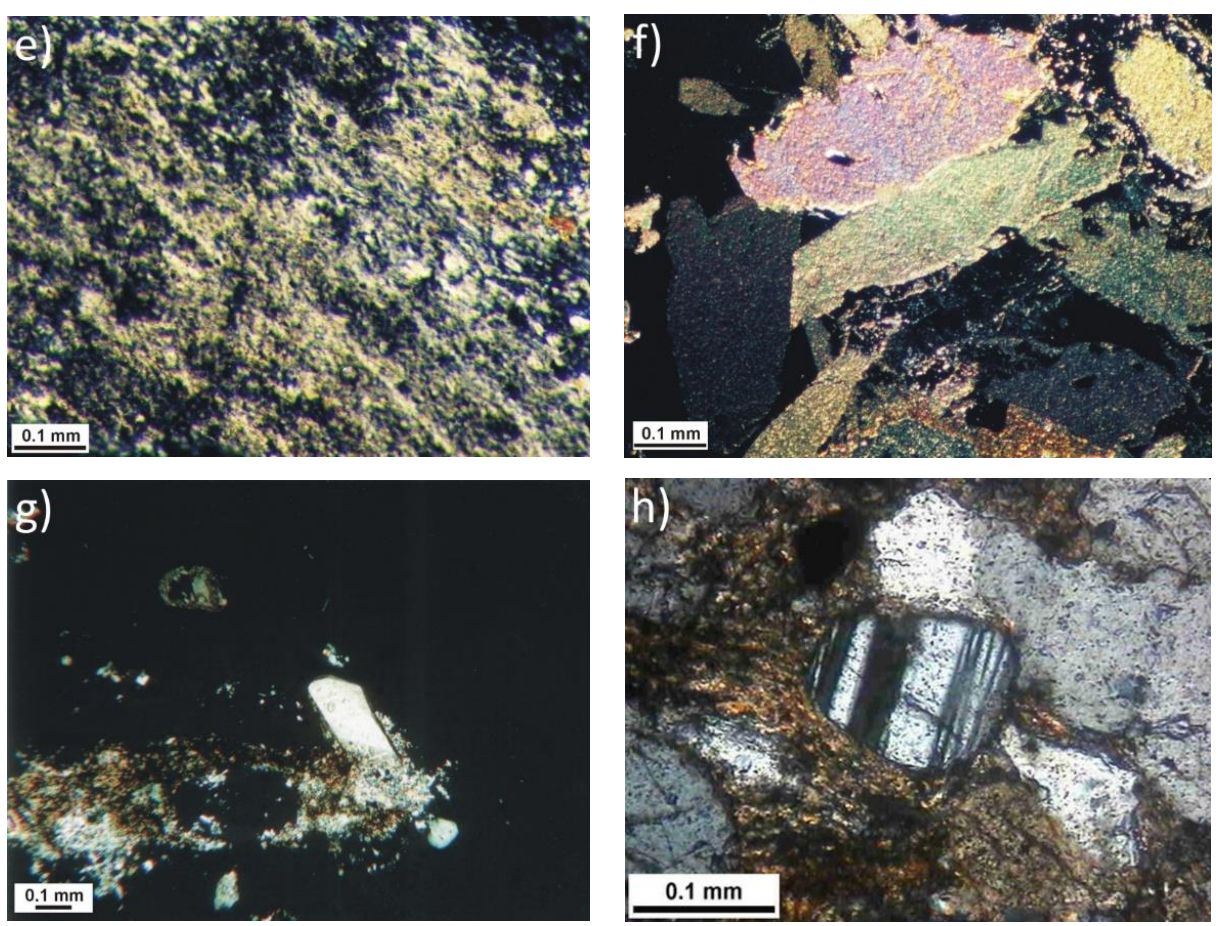

Figure 5. Mineral composition of the zuber rocks (according to [41,45,46]). (a) Fractures in halite filled with fine-grained anhydrite (Anh); (b) secondary crystallized fine-grained halite; (c) fluid inclusions in halite; (d) idiomorphic crystals of anhydrite (Anh) in a fine-grained matrix; (e) typical clayey-quartz fine-grained concentration with parallel grains orientation; (f) coarse-grained calcite concentration; (g) clayey-anhydrite (clay-anh) concentration with isomorphic quartz crystals; (h) plagioclase (plag) with xenomorphic crystals of quartz (qtz). Image (a) — partially cross polarized light; images (b,c) — plane polarized light; images $(\mathbf{d}-\mathbf{h})$ — cross polarized light.

\subsection{Loss of Mass and Thermal Expansion as a Result of Heating}

Loss of mass during heating is strictly connected to the loss of water occurring in zuber rocks. Generally, rock salt and the accompanying minerals contain small quantities of water. Water occurs in the intergranular pores, liquid inclusions and in hydrated and clay minerals. Zuber rock samples were heated in the temperature range of $80-140^{\circ} \mathrm{C}$ to determine the mass loss and expansion changes as a result of the gradual heating of the rocks.

The results were compared to the results of the mineralogical study and chemical tests to learn about the mechanism of those phenomena. The results of the tests indicate that the average mass loss in the Brown Zuber unit samples was about $1.1 \%$ at $140{ }^{\circ} \mathrm{C}$, and in the Red Zuber unit samples it was about $1.9 \%$. The maximum mass loss of $2.5 \%$ was recorded for the Red Zuber unit sample and minimum mass loss of $0.7 \%$ was recorded for the sample of the Brown Zuber unit. In the case of rock salt, the mass loss was very low at around $0.1 \%$ at $140{ }^{\circ} \mathrm{C}$ [46]. The relative sample mass changes with respect to the original mass, depending on temperature, are presented in Figure 6. 


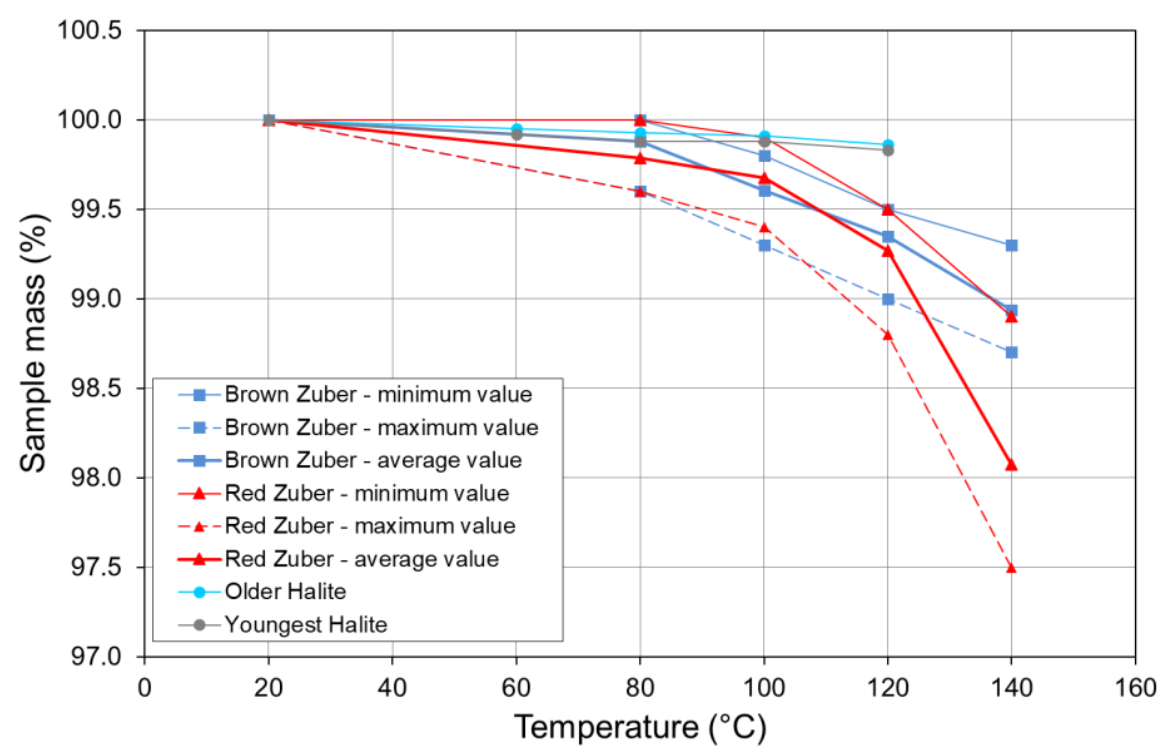

Figure 6. Zuber rock and rock salt mass loss dependence on temperature (according to [46]).

The results of the respective tests indicated that in addition to water-insoluble minerals content, heating time is the second important factor influencing the samples mass loss [34,35]. The volume changes exceeding $1 \%$ occurred during $24 \mathrm{~h}$ of the experiment. Later, in this range of temperature, the loss of mass was insignificant. Research on the Brown Zuber unit rocks carried out by [41] indicates an increase in mass loss with an increase in the content of the water-insoluble minerals to about 50-60\%, at which it reaches maximum values. In samples with higher water-insoluble minerals content, the mass loss value decreases (Figure 7).

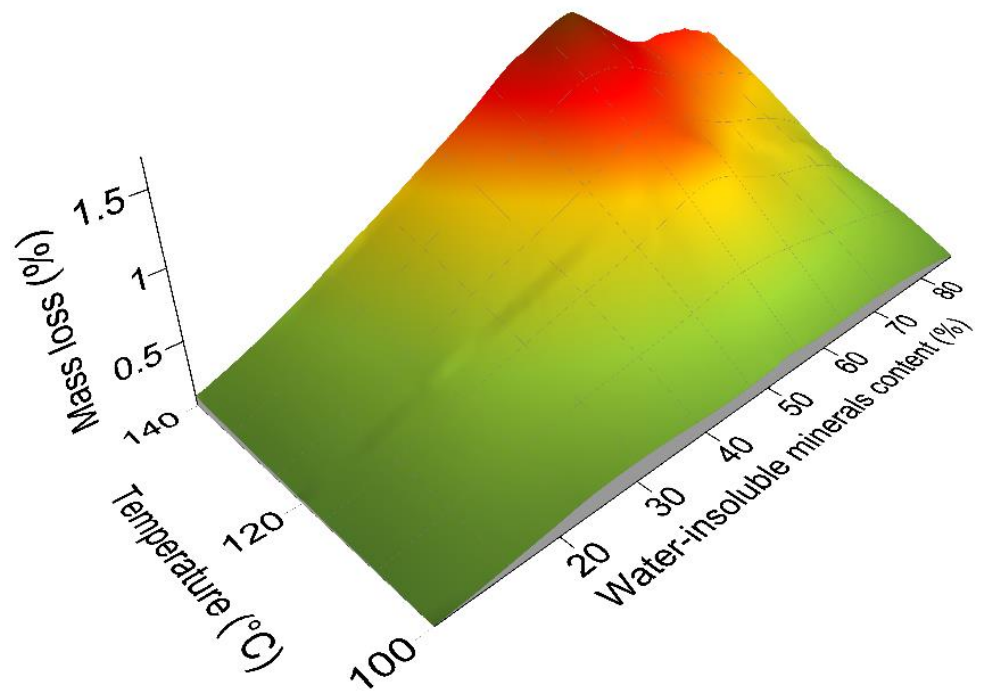

Figure 7. Mass loss of the Brown Zuber unit samples, depending on temperature and on the water-insoluble minerals content.

Due to the temperature range applied in the experiment, only intergranular water could have been released. Water occurring in fluid inclusions and bound in hydrated minerals could be released in higher temperatures [47]. Microscopic observations of halite crystals also indicated that liquid inclusions were not destructed at temperatures of up to $120^{\circ} \mathrm{C}$ in the majority of cases. Consequently, they were not the sources of evaporated water. It is not possible to exclude, however, that long-term exposure to high temperatures could lead to partial destruction of inclusions. The released water could enhance the pressure-solution creep in association with the dislocation creep [48-50] and lead to the 
decrease in strength at high strain rates [51]. Water occurring in rock salt structures has the form of saturated brine. Therefore, it does not have any leaching properties and does not cause dissolution of halite or any other easily soluble salts accompanying zuber rocks, except for the grain boundary migration process [52,53]. It should be emphasized that the loss of the intergranular water of the zuber rock samples being tested in the laboratory conditions could not exactly reflect processes occurring in situ in the salt dome. The phenomenon of thermally induced mass loss and brine migration should be considered in the time aspect, since zuber rock heating, caused by the presence of heat-generating nuclear waste, would continue for a very long period.

Thermal expansion measurements were intended to determine the rock expansion coefficients and to check whether cracks appear in zuber rocks under variable temperature conditions [46]. Samples were heated at temperatures of $80^{\circ} \mathrm{C}, 100^{\circ} \mathrm{C}, 120^{\circ} \mathrm{C}$ and $140^{\circ} \mathrm{C}$ during $24 \mathrm{~h}$. After each heating phase, rock observations were performed, using reflected light microscopy.

The samples heated to $100{ }^{\circ} \mathrm{C}$ were also observed in thin sections applying transmitted light microscopy. Special attention was paid to the boundaries between the particular mineral phases, the internal structure of the halite and the detrital materials.

The tested samples did not show directional textures. Consequently, one can assume that the sample size changes during heating were similar in all directions. The relative thermal expansion is expressed by Formula (1):

$$
\frac{h-h_{0}}{h_{0}} \cdot 100 \%
$$

where:

$h_{0}$-initial sample length;

$h$-sample length after heating.

The results of the tests indicate that the average relative expansion of the Brown Zuber unit samples was about $0.4 \%$ at $140{ }^{\circ} \mathrm{C}$, and of the Red Zuber unit samples was about $0.2 \%$. The maximum relative expansion of $0.7 \%$ was recorded in case of the Brown Zuber unit sample and minimum of $-0.3 \%$ for the sample of the Red Zuber unit $[46,54,55]$. The extreme and average relative thermal expansion values of the tested samples are presented in Figure 8.

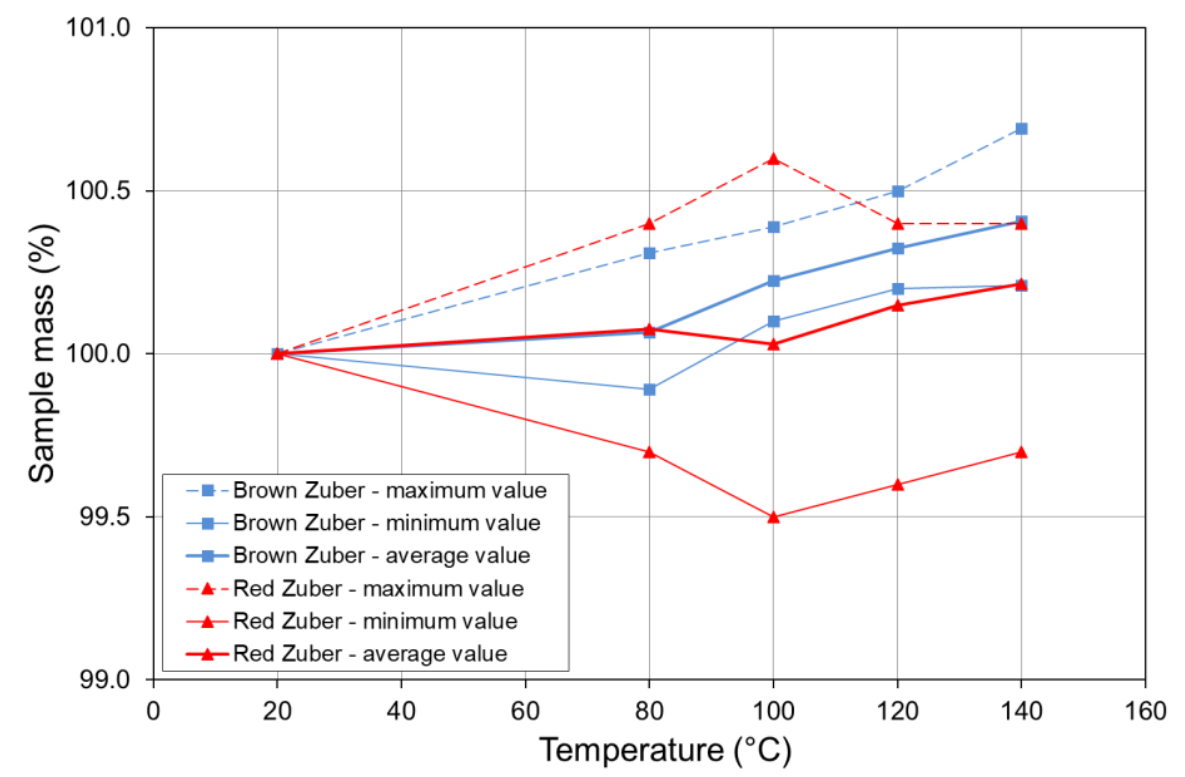

Figure 8. Zuber rock relative thermal expansion depending on temperature (according to [46]).

Halite found in the Brown and Red Zuber unit samples was represented by the crystals of several generations. Those were cracked locally to various extent. Observations of the contact zones between various halite crystals indicated that either there were no cracks, or they may have existed 
in submicroscopic dimensions. Cracks were most frequently propagating in the zones of occurrence of the ingrowths of other minerals or gaseous-liquid inclusions, where halite crystal structures were weakened. Small fractures in detrital mass accompanying halite were also observed. Those were found especially in samples with a large share of clay minerals. The cracks in the halite crystal showed a different nature than those in the detrital mass. They were straight-line formations repeating the system of natural cleavage planes of that mineral. However, the crack propagation was irregular and diminishing in the surrounding detrital minerals.

Heating of samples did not cause any essential structural or textural changes. Even at temperatures of $140{ }^{\circ} \mathrm{C}$, no significant cracking system changes were recorded in the microscopic images. Heating at temperatures of up to $140{ }^{\circ} \mathrm{C}$ leads to small volumetric changes of ca. $1 \%$ mass loss, mainly owing to loss of water from the detrital part and the occurrence of sporadic and small cracks mainly in halite. No thermal cracking was observed on the contact zone between the detrital substance and the halite, despite the differences in their thermal properties [46].

\subsection{Sorption Properties}

The sorption tests were conducted in the Isotopic Laboratory of the Department of Radiometry of the Faculty of Physics and Nuclear Technology of AGH. Laboratory experiments, with the use of radioactive isotopes ${ }^{90} \mathrm{Sr}+{ }^{90} \mathrm{Y}$ and ${ }^{152,154} \mathrm{Eu}$ were carried out on monolithic and granulated (grain diameter of 2-5 mm) samples of the Brown and Red Zuber units, as well as on the rock salt [56].

The isotopes of ${ }^{90} \mathrm{Sr}+{ }^{90} \mathrm{Y}$ were selected owing to their high share in SNF, while the isotopes of ${ }^{152,154} \mathrm{Eu}$ are generally considered to be a homologue of ${ }^{241} \mathrm{Am}$, representing transuranians.

The fraction $\mathrm{F}$ of the isotope adsorbed from brine containing radioactive isotopes is determined by the following equation:

$$
F=\left|\frac{I-I_{0}}{I_{0}}\right|
$$

where:

$I_{0}$ - initial frequency of the decay counts in the solution of radioactive isotopes in brine;

I-frequency of the decay counts in specific time after granulated sample addition.

The fraction $F$ reaches the value of 1 for complete sorption of radioactive isotopes by the sample (the frequency of the decay counts $I=0$ ). The $\mathrm{F}$ values of isotopes ${ }^{152,}{ }^{154} \mathrm{Eu}$ and ${ }^{90} \mathrm{Sr}+{ }^{90} \mathrm{Y}$ obtained in the tested rock samples at room temperature are presented in Figures 9 and 10, respectively.

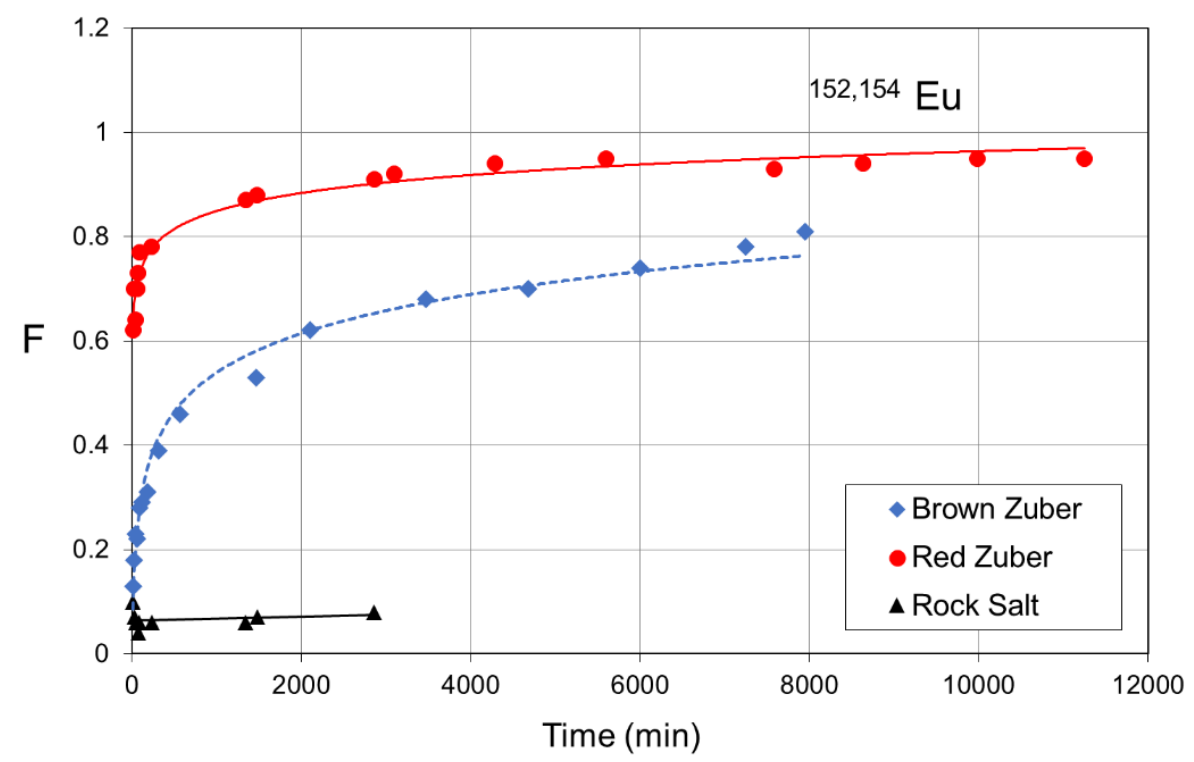

Figure 9. Sorption of the ${ }^{152,154} \mathrm{Eu}$ isotope of the Brown and Red Zuber unit samples and rock salt samples (according to [56]). 


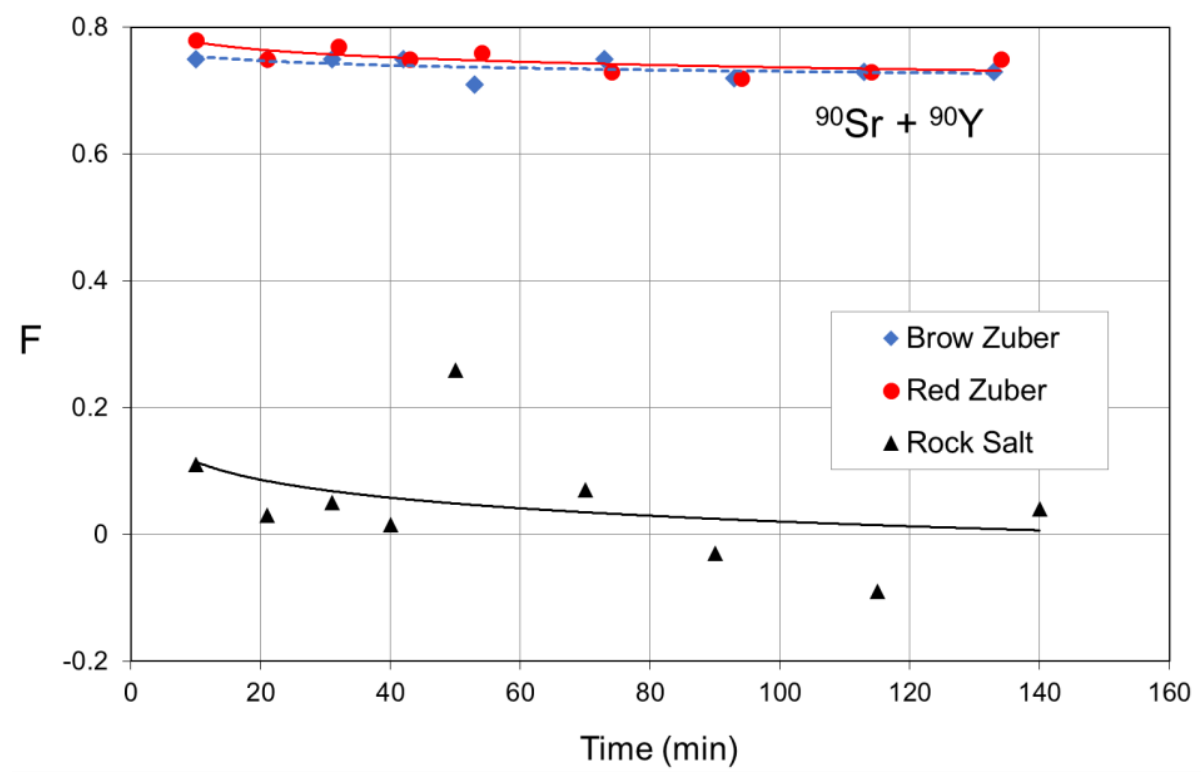

Figure 10. Sorption of the ${ }^{90} \mathrm{Sr}+{ }^{90} \mathrm{Y}$ isotope of the Brown and Red Zuber unit samples and rock salt samples (according to [56]).

The obtained results demonstrated that fraction of water-insoluble minerals occurring in zuber rocks in contrast to rock salt has high sorption capability to immobilize permanently such radionuclides as ${ }^{90} \mathrm{Sr}$ and ${ }^{152,154} \mathrm{Eu}$. It was found that, in the case of the isotope ${ }^{90} \mathrm{Sr}$, probably three different mechanisms could be responsible for immobilization: sorption, exchange of strontium ions with those of calcium and precipitation of strontium sulphate $\left(\mathrm{SrSO}_{4}\right)$ resulting from the chemical composition of zuber rocks containing $\mathrm{SO}_{4}{ }^{2-}$ ions. The specified mechanisms depend on temperature: the capability of sorption decreases and the strontium sulphate solubility increases with the increase in temperature. No significant influence of brine composition on the course of sorption was found (tests were conducted with the use of sodium-chloride and magnesium-chloride brines). In the case of the tests conducted on monolithic samples, it was found that the radionuclides were penetrating into the host rock. The related autoradiograms indicate that the radionuclides migrated a small distance through the clay fraction in which they were retained [56]. The above conclusions confirm that both the Brown and Red Zuber unit rocks could be a geological barrier that would efficiently immobilize radionuclides in the case of a HLW or SNF canister failure.

\subsection{Geomechanical Properties}

The tests of the geomechanical properties included three types of experiments: (1) ultrasound testing, (2) short-time tests of strength and deformation and (3) creep and relaxation tests concerning rheological properties [25,33-36].

\subsubsection{Ultrasound Testing}

Ultrasound tests were conducted in the first phase on the samples of $2.5 \mathrm{~cm}$ in diameter and they consisted of the measurements of compressional P-wave velocity $\left(V_{P}\right)$ and surface wave velocity $\left(V_{R}\right)$ in parallel to the sample axis. Because of strong attenuation of the shear S-wave energy, its velocity, necessary for the determination of dynamic moduli of elasticity, was determined on the basis of the surface wave velocity $\left(V_{R}\right)$. In the second phase of the research, tests were conducted on the samples of $5 \mathrm{~cm}$ in diameter and the P-wave velocity was determined in perpendicular and parallel directions to the sample axis. The test results are presented in Table 1. 
Table 1. Results of the ultrasound testing of the zuber rock samples (according to [57]).

\begin{tabular}{|c|c|c|c|c|c|c|c|}
\hline \multirow[b]{2}{*}{$\begin{array}{l}\text { Type of } \\
\text { Wave }\end{array}$} & \multirow[b]{2}{*}{ Phase } & \multicolumn{3}{|c|}{ Brown Zuber } & \multicolumn{3}{|c|}{ Red Zuber } \\
\hline & & $\begin{array}{c}\text { Velocity } \\
\text { Measured } \\
\text { Parallel to the } \\
\text { Sample Axis } \\
(\mathrm{m} / \mathrm{s})\end{array}$ & $\begin{array}{c}\text { Velocity } \\
\text { Measured } \\
\text { Perpendicular } \\
\text { to the Sample } \\
\text { Axis }(\mathrm{m} / \mathrm{s})\end{array}$ & $\begin{array}{c}\text { Average } \\
\text { Anisotropy } \\
\text { Coefficient }\end{array}$ & $\begin{array}{c}\text { Velocity } \\
\text { Measured } \\
\text { Parallel to the } \\
\text { Sample Axis } \\
(\mathrm{m} / \mathrm{s})\end{array}$ & $\begin{array}{c}\text { Velocity } \\
\text { Measured } \\
\text { Perpendicular } \\
\text { to the Sample } \\
\text { Axis }(\mathrm{m} / \mathrm{s})\end{array}$ & $\begin{array}{l}\text { Average } \\
\text { Anisotropy } \\
\text { Coefficient }\end{array}$ \\
\hline \multirow{2}{*}{$V_{P}$} & I & $3551-4882$ & & & $3857-5238$ & & \\
\hline & II & $3562-4500$ & $3403-4633$ & 0.97 & $3062-4137$ & $1857-4800$ & 0.75 \\
\hline \multirow{2}{*}{$V_{R}$} & I & $1828-2130$ & & & & & \\
\hline & II & $1962-2198$ & 1794-2206 & 1.01 & 1470-2071 & 1144-2109 & 1.01 \\
\hline
\end{tabular}

The data presented in Table 1 indicate that the elasticity parameters of zuber rocks are strongly diversified, and the Red Zuber unit samples display higher anisotropy and a larger dispersion of parameter values. The tests allowed to determine the value of the modulus of elasticity $\left(E_{d}\right)$ and the Poisson's ratio. The value of the dynamic modulus of elasticity $\left(E_{d}\right)$ changes in the range from 16.9 to $54.7 \mathrm{GPa}$, while that of the dynamic Poisson's ratio from 0.09 to 0.38 and indicate the poor elastic properties of zuber rocks.

\subsubsection{Deformation and Strength Tests}

The purpose of the deformation and strength tests was to determine the values of elasto-plastic strain, with the identification of the elastic components and the determination of the strength indicators, i.e., ultimate stresses and strains at sample failure. The experiments included two types of tests: tests with a constant stress rate and tests with a constant strain rate.

Eighteen zuber rock samples (nine for each type of zuber units) in each of the two research phases were tested at constant stress rate conditions. The sample diameter was $44 \mathrm{~mm}$ with a slenderness of $\lambda=2$. Three different values of the confining pressure of $\sigma_{3}=2,5$, and $10 \mathrm{MPa}$ were applied. The rate of axial stress was $0.1 \mathrm{MPa} \cdot \mathrm{s}^{-1}$. Similar results were obtained in both phases (Table 2). The stress-strain characteristics obtained in the second phase for the Brown and Red Zuber unit samples are presented in Figures 11 and 12, respectively.

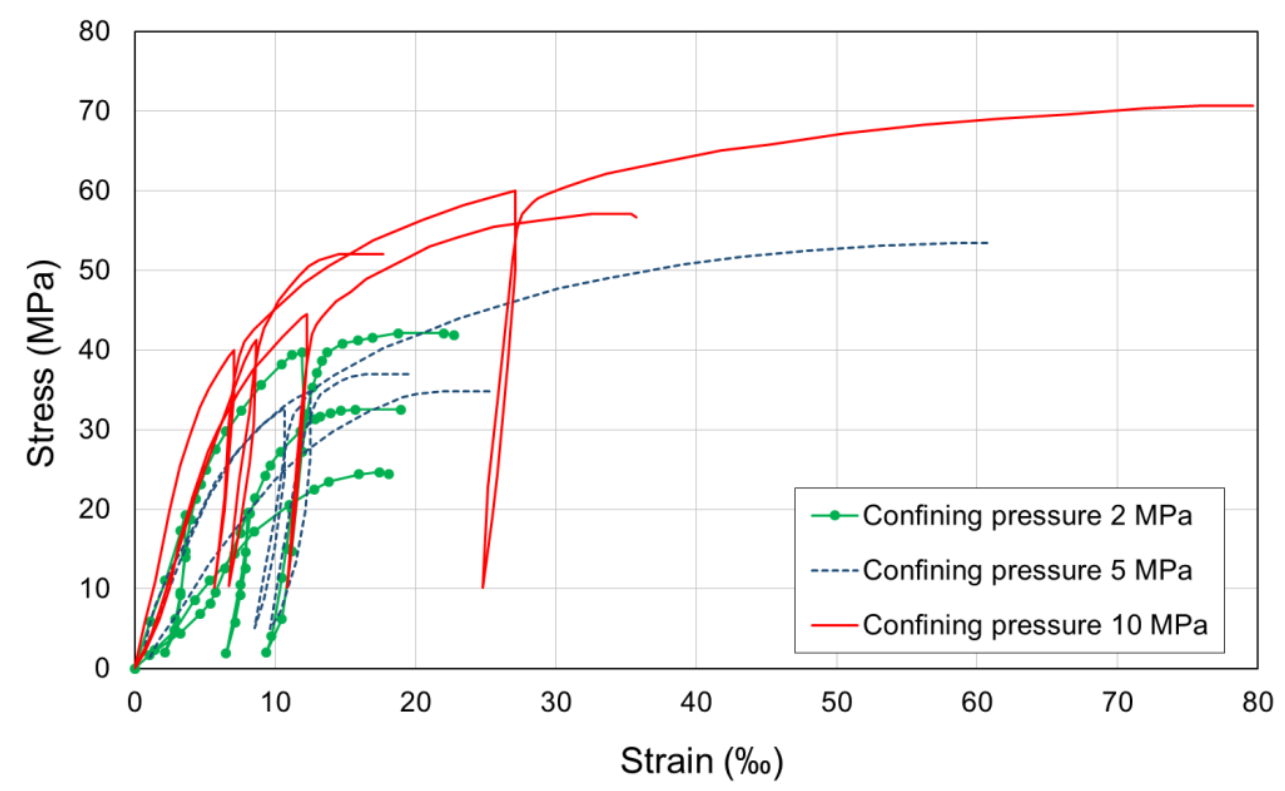

Figure 11. Stress-strain characteristics of the Brown Zuber unit samples-conventional triaxial compression tests at a constant stress rate (according to [58]). 


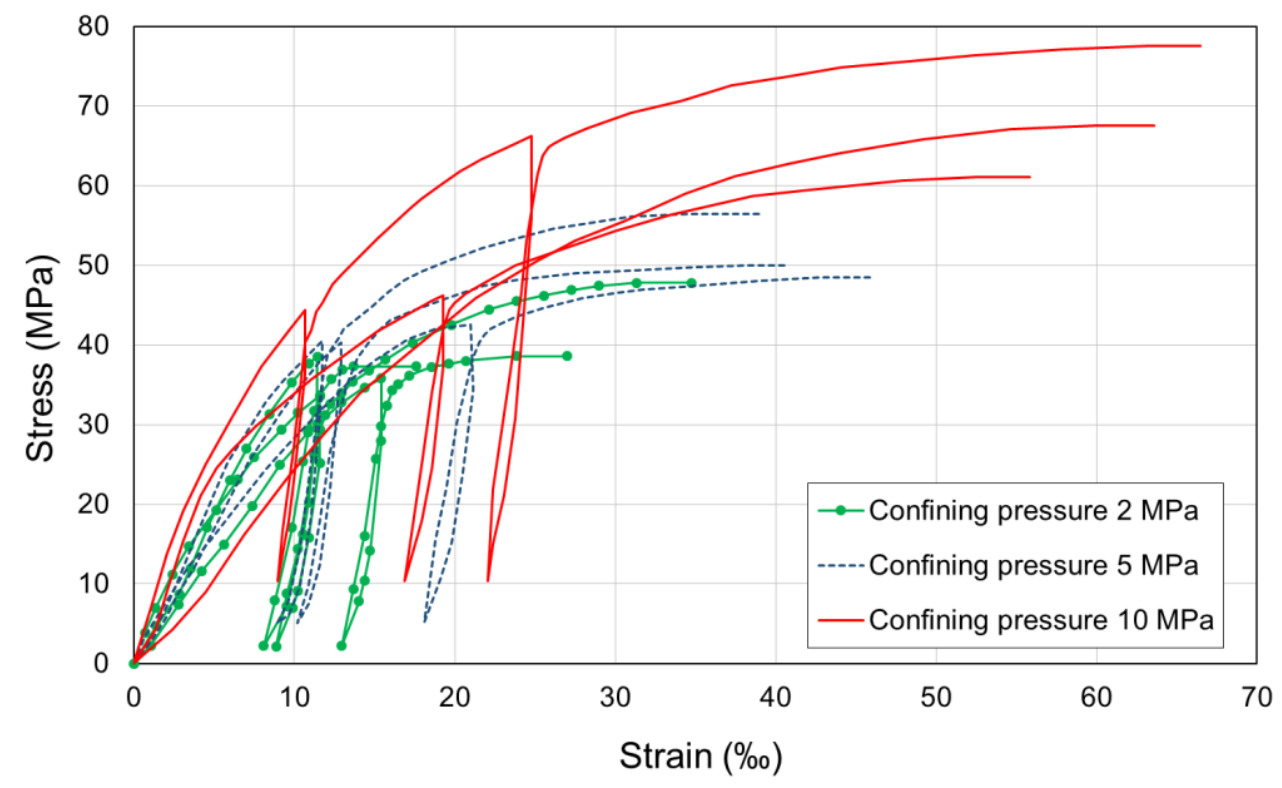

Figure 12. Stress-strain characteristics of the Red Zuber unit samples-conventional triaxial compression tests at a constant stress rate (according to [58]).

The samples tested in constant strain-rate conditions had a diameter of $2.5 \mathrm{~cm}$ in the first phase of research and $5 \mathrm{~cm}$ in the second. In both phases, the slenderness of the samples was $\lambda=2$ and the confining pressure was $\sigma_{3}=5 \mathrm{MPa}$. In the first phase, 12 samples were tested, with the strain rate $d \varepsilon_{1} / d t$ of $5 \times 10^{-6} \mathrm{~s}^{-1}$ or $1 \times 10^{-5} \mathrm{~s}^{-1}$. In the second phase, 18 compression tests were conducted with the strain rate of $5 \times 10^{-6} \mathrm{~s}^{-1}, 1 \times 10^{-5} \mathrm{~s}^{-1}$ or $1 \times 10^{-4} \mathrm{~s}^{-1}$. The triaxial compression tests at a constant stress rate and constant strain rate were conducted on samples very similar in dimensions, to obtain the comparable results and avoid specimens size effect on the triaxial compressive strength.

The stress-strain characteristics of the Brown and Red Zuber unit samples obtained in the second testing phase are presented in Figures 13 and 14, respectively. Figure 13a,b show the axial and volumetric strain curves of the Brown Zuber unit samples, respectively, and Figure 14a,b show the axial and volumetric strain curves of the Red Zuber unit samples.

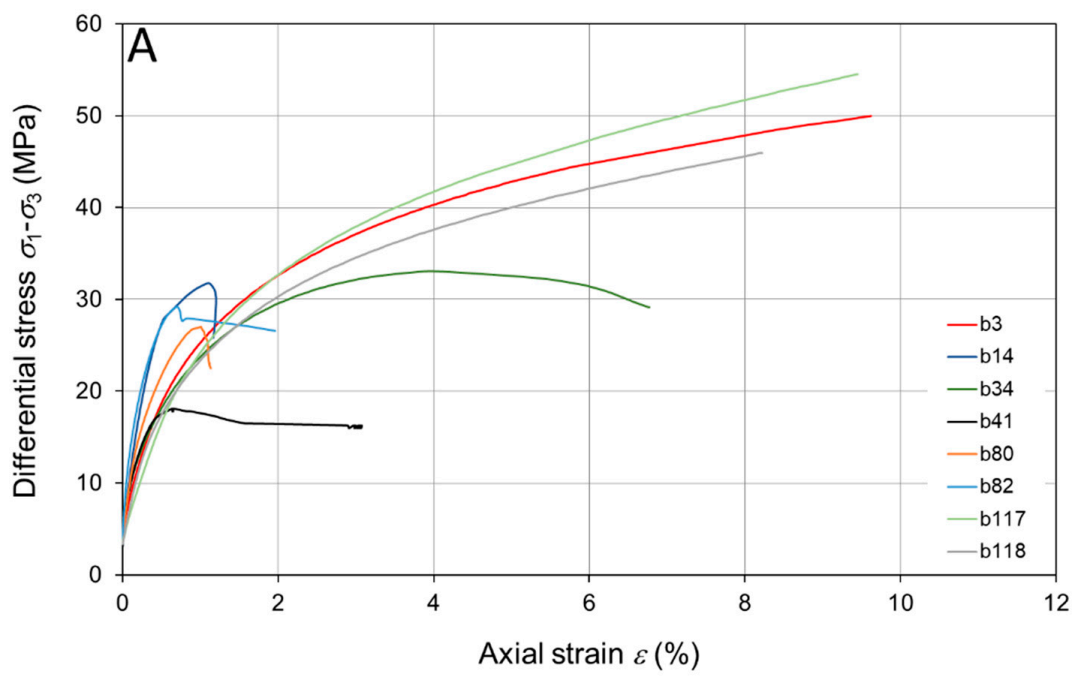

Figure 13. Cont. 


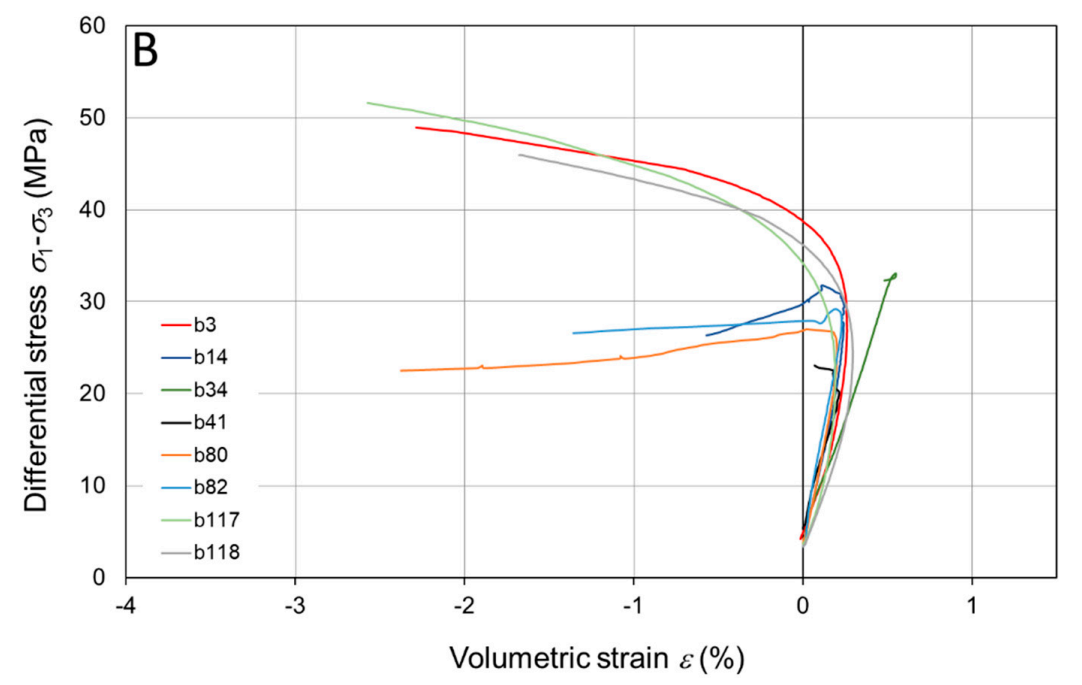

Figure 13. Stress-strain characteristics of the Brown Zuber unit samples in the tests at a constant strain rate. (A) —axial strain; (B) — volumetric strain (according to [57]).
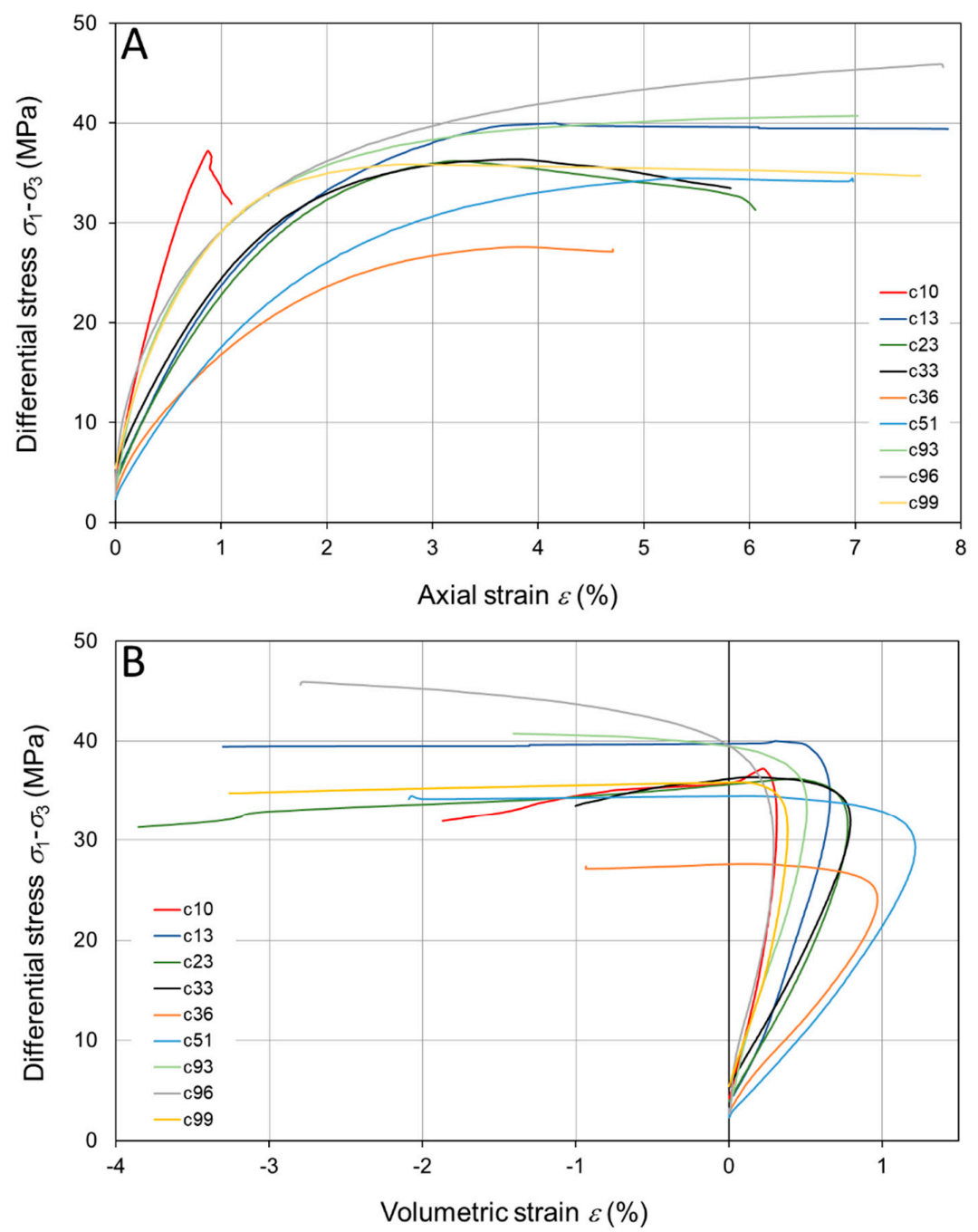

Figure 14. Stress-strain characteristics of the Red Zuber unit samples in the tests at a constant strain rate. (A)—axial strain; (B)—volumetric strain (according to [57]). 
The maximum values of differential stress and axial strain are presented in Table 2. The detailed results of the short-term compression tests are presented in Table A1.

Table 2. Maximum values of differential stress $\left(\sigma_{1}-\sigma_{3}\right)$ and axial strain $\left(\varepsilon_{1}\right)$ obtained in the conventional triaxial compression tests.

\begin{tabular}{ccccccc}
\hline \multirow{2}{*}{ Type of Test } & \multicolumn{3}{c}{ Constant Rate of Stress } & \multicolumn{3}{c}{ Constant Rate of Strain } \\
\cline { 2 - 7 } & $\sigma_{\mathbf{3}} \mathbf{( M P a )}$ & $\sigma_{\mathbf{1}}-\sigma_{\mathbf{3}} \mathbf{( M P a )}$ & $\varepsilon_{\mathbf{1}} \mathbf{( \% )}$ & $\left.d \varepsilon_{\mathbf{1}} / d t \mathbf{s}^{-\mathbf{1}}\right)$ & $\sigma_{\mathbf{1}}-\sigma_{\mathbf{3}} \mathbf{( M P a )}$ & $\varepsilon_{\mathbf{1}} \mathbf{( \% )}$ \\
\hline Brown & 2 & $37.8-41.4$ & $1.6-4.0$ & $1 \times 10^{-6}$ & $14.7-54.0$ & $5.8-9.7$ \\
Zuber & 5 & $44.3-48.3$ & $5.9-7.4$ & $1 \times 10^{-5}$ & $19.0-24.8$ & $4.0-6.2$ \\
Phase I & 10 & $47.2-60.4$ & $6.8-7.3$ & & & \\
\hline Brown & 2 & $22.7-40.1$ & $1.6-2.2$ & $1 \times 10^{-6}$ & 39.9 & 6.1 \\
Zuber & 5 & $29.8-48.4$ & $1.6-5.9$ & $1 \times 10^{-5}$ & $18.1-45.9$ & $0.6-8.2$ \\
Phase II & 10 & $42.0-60.7$ & $1.5-7.6$ & $1 \times 10^{-4}$ & $27.0-54.5$ & $1.0-9.6$ \\
\hline \multirow{2}{*}{ Red Zuber } & 2 & $39.4-43.4$ & $1.4-3.4$ & & & \\
Phase I & 5 & $37.1-45.6$ & $3.1-3.8$ & $1 \times 10^{-5}$ & $9.5-22.3$ & $1.2-4.9$ \\
& 10 & $53.8-68.3$ & $2.6-5.9$ & & & \\
\hline \multirow{2}{*}{ Red Zuber } & 2 & $35.3-45.7$ & $1.4-3.1$ & $1 \times 10^{-6}$ & 45.9 & 7.8 \\
Phase II & 5 & $43.4-51.4$ & $3.5-4.3$ & $1 \times 10^{-5}$ & $27.6-40.4$ & $3.8-6.7$ \\
& 10 & $51.1-67.6$ & $5.2-6.3$ & $1 \times 10^{-4}$ & $35.9-37.2$ & $0.9-3.8$ \\
\hline
\end{tabular}

The tests results indicated that the strength of the tested samples depended on the water-insoluble minerals content, which is illustrated by Figures 15 and 16, presenting the values of differential stress at the moment of sample failure, during the tests with a constant stress and constant strain rate, respectively.

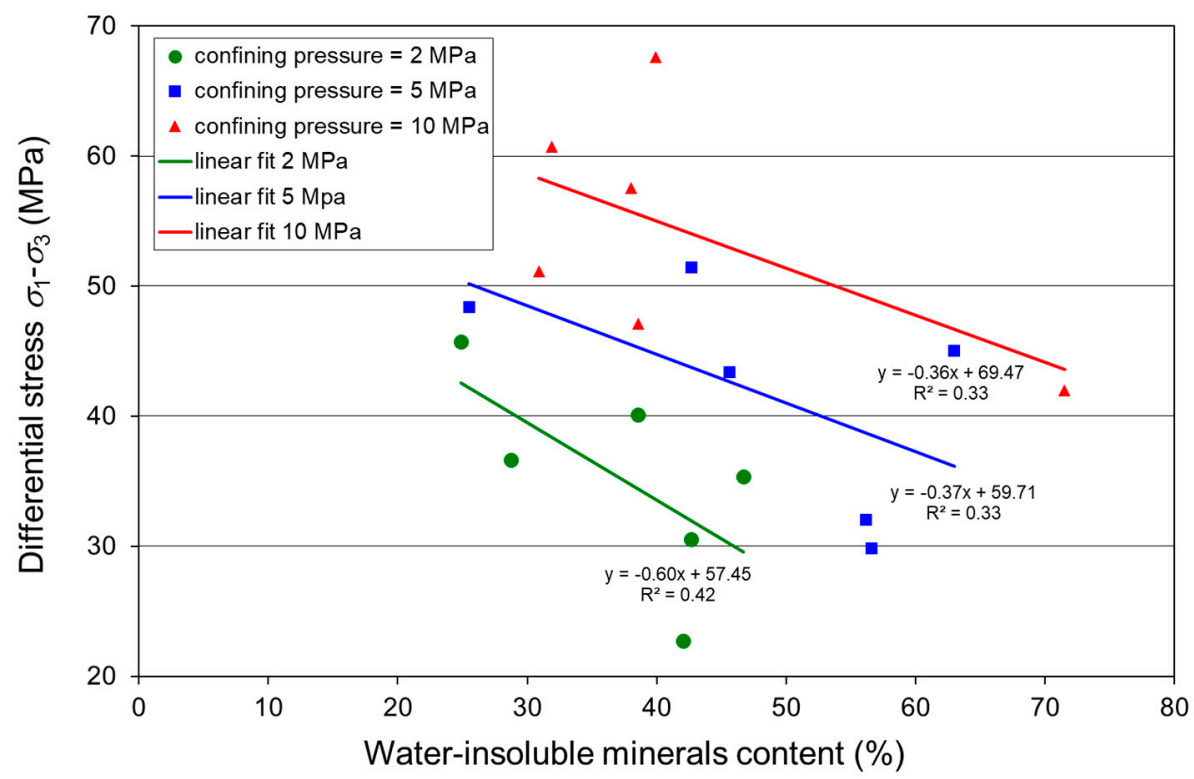

Figure 15. Dependence of the maximum differential stress value $\left(\sigma_{1}-\sigma_{3}\right)$ on water-insoluble minerals content- - tests with a constant stress rate. 


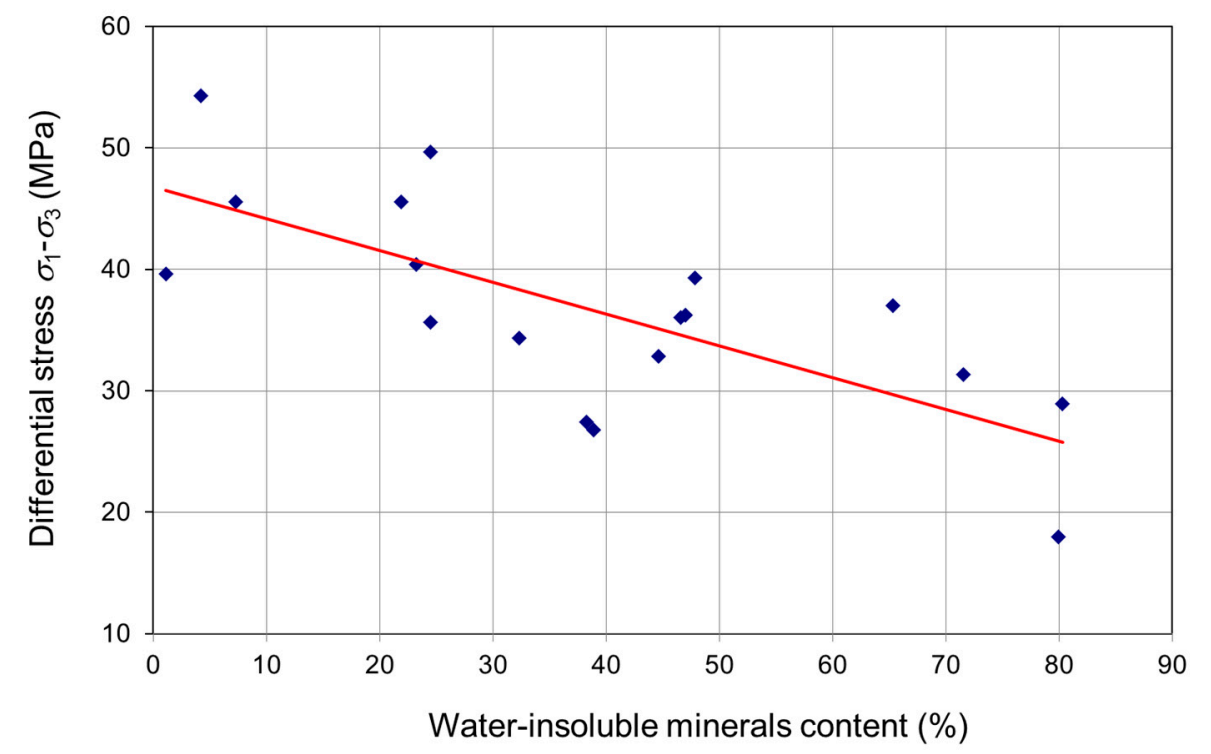

Figure 16. Dependence of the maximum differential stress value $\left(\sigma_{1}-\sigma_{3}\right)$ on water-insoluble minerals content- tests with a constant strain rate (according to [57]).

The results of the conducted tests indicate that the strength and deformational features of the zuber rocks samples depend on the water-insoluble minerals content. As the water-insoluble minerals content increases, the total axial strain and the differential stress value decrease. The increased content of water-insoluble minerals also reduces axial and volumetric strains. The load rate did not influence the strength of the tested rocks. The strength of the tested zuber rock samples was slightly lower than the lower strength limit obtained for the rock salt samples. In the case of the tests at a confining pressure of $2 \mathrm{MPa}$, the strength values obtained were within the range of strength of weak rock salt. The value of ultimate strain of the zuber rock samples was more than two times lower than that of the rock salt and the difference was increasing with the confining pressure increase.

\subsubsection{Rheological Properties}

Creep is the irreversible deformation that increases with time under constant load and is that part of the geomechanical behavior that has the greatest influence on the time dependent strain and stress evolution in the surrounding rock massif. The creep behavior of rock salt is of special interest for underground repositories for radioactive wastes. Creep is time-dependent deformation and it goes through there stages: primary (transient) creep, in which the strain rate is relatively high and decreases with time, followed by steady-state creep, with the constant and slow strain increase, and the final stage, in which the strain rate rapidly accelerates, leading to ultimate material failure [59-61].

The research included 40 conventional creep tests in which the axial stress was higher than the confining pressure. In 32 tests, the confining pressure value was $5 \mathrm{MPa}$, and the axial stress values were in the range from 12.5 to $25 \mathrm{MPa}$ (i.e., differential stresses were changing from 7.5 to $20 \mathrm{MPa}$ ). The temperature of the samples was changing during the experiments from room temperature to $90^{\circ} \mathrm{C}$. In the remaining eight uniaxial creep tests conducted at room temperature, the axial stress value was $8 \mathrm{MPa}$. In a considerable number of tests, the stress and temperature conditions were changed during the experiment, which caused that the testing periods ranged from 55 to 889 days. An example of a zuber rock sample test, conducted at constant stress and temperature conditions, is presented in Figure 17, and an example of the course of the longest tests, in which the differential stress values were changing from 7.5 to $15 \mathrm{MPa}$ and the temperature ranged from 35 to $60^{\circ} \mathrm{C}$, is presented in Figure 18 . The detailed results of the multi-step rheological tests are presented in Tables A2 and A3. 

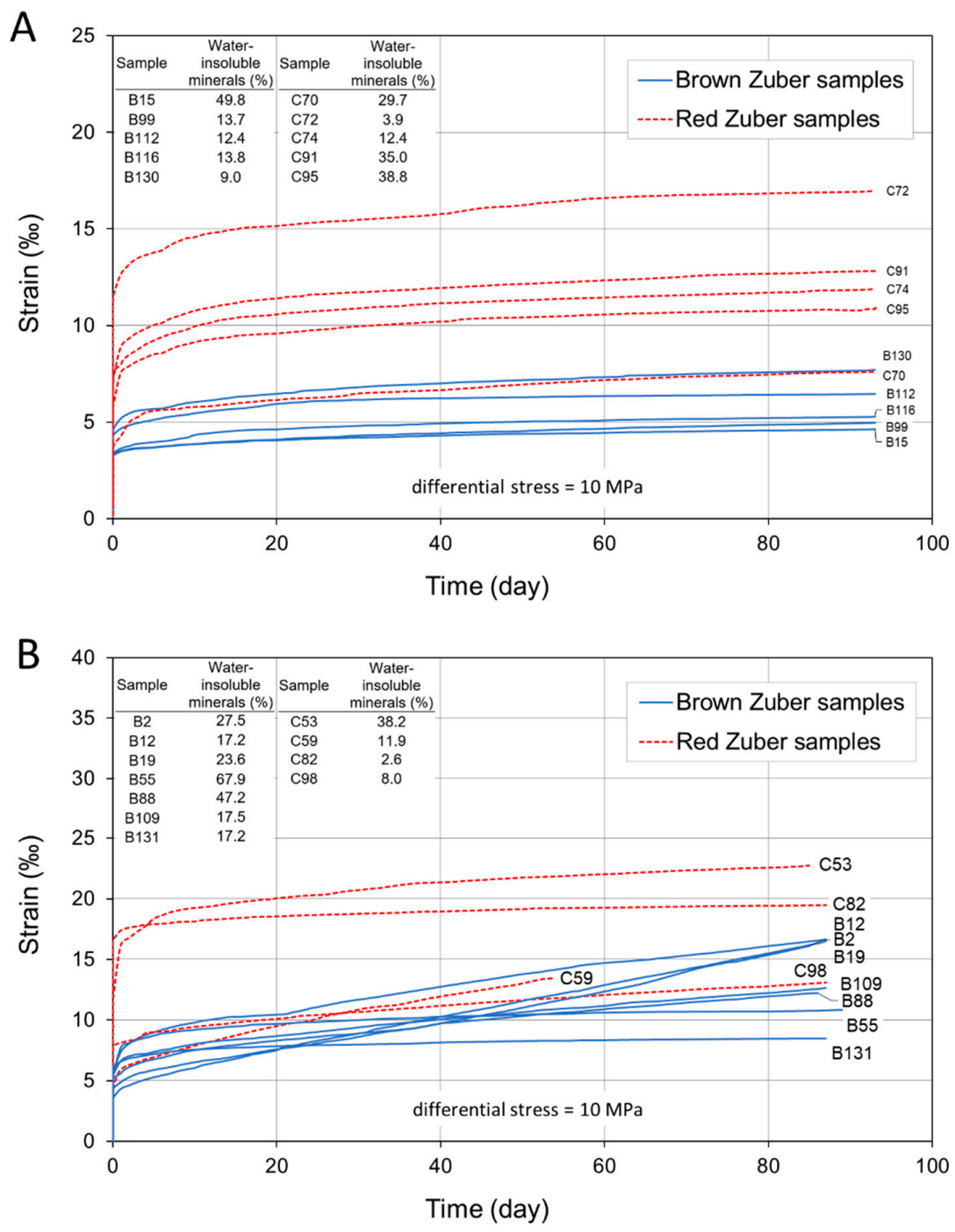

Figure 17. Long-term creep curves of the Brown and Red Zuber unit samples at a constant pressure and at room temperature (A) and at a temperature of $60^{\circ} \mathrm{C}(\mathbf{B})$ (according to [58]).

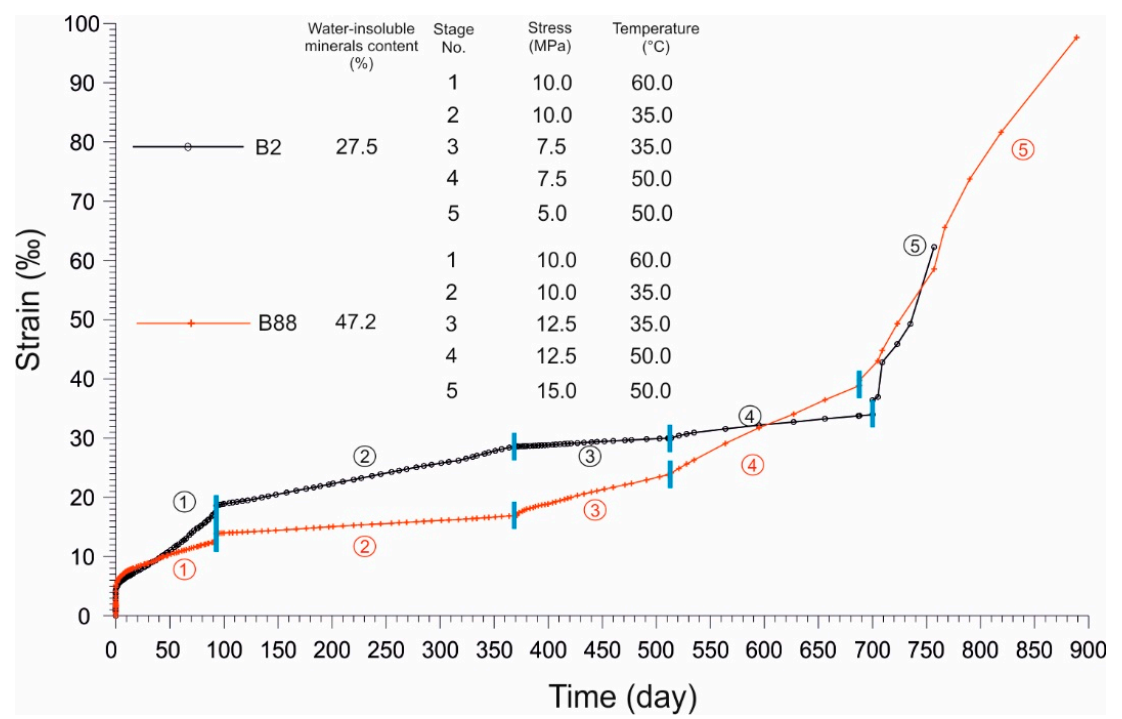

Figure 18. Long-term creep curves of the Brown Zuber unit samples at changing stress and temperature conditions (according to [58]). 
Eight uniaxial creep tests were designed to determine the influence of humidity on creep rate. For that reason, four zuber rock samples were sprayed with saturated brine and protected with plastic foil. The comparison of the creep curves in both types of samples is presented in Figure 19. Tests results confirmed the strong impact of brine on the increase in creep-rate values. Test conditions led to the failure of one sample already in the transient creep phase.

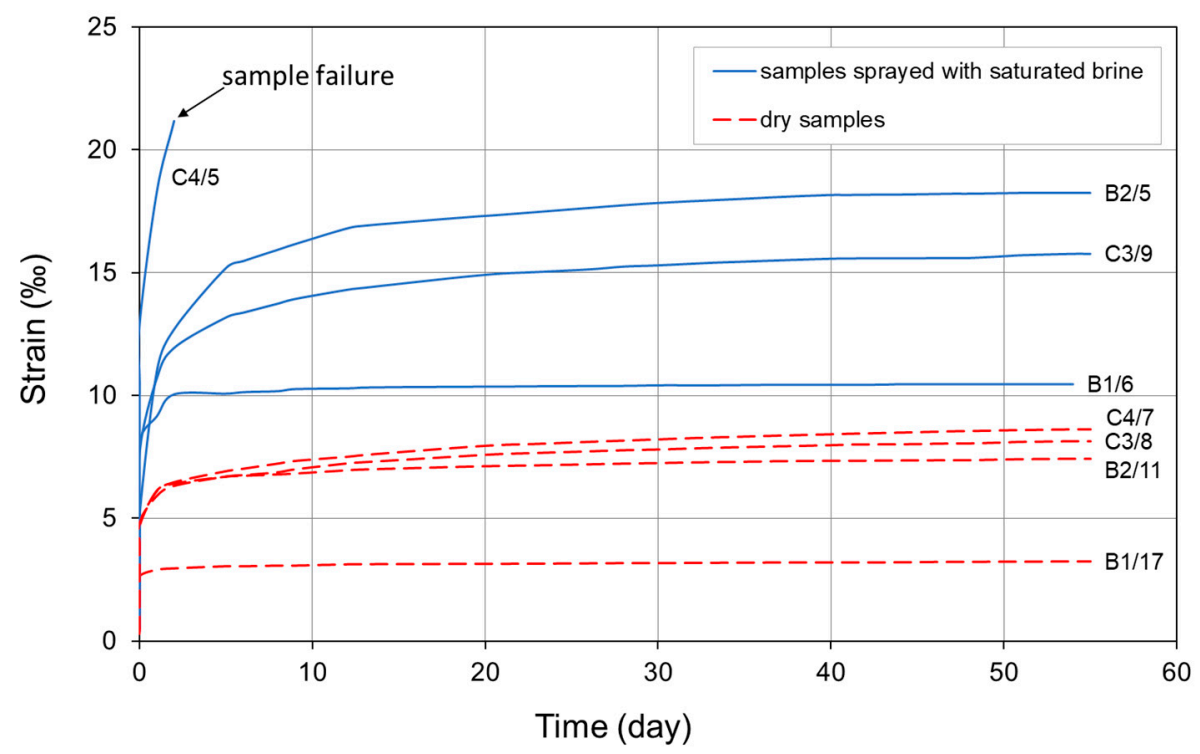

Figure 19. Creep curves of dry and saturated brine-sprayed samples $\left(\sigma_{1}=8 \mathrm{MPa}\right)$.

Another purpose of the conducted tests was to determine the influence of the water-insoluble content on the creep rates. Figure 20 presents the steady-state creep rates of the samples with various water-insoluble minerals contents at room temperature and at temperatures of $60^{\circ} \mathrm{C}$. The results do not indicate a clear influence of the water-insoluble minerals content on creep rate in both temperatures. That is especially significant in view of the essential influence of the water-insoluble minerals content on zuber rocks strength.

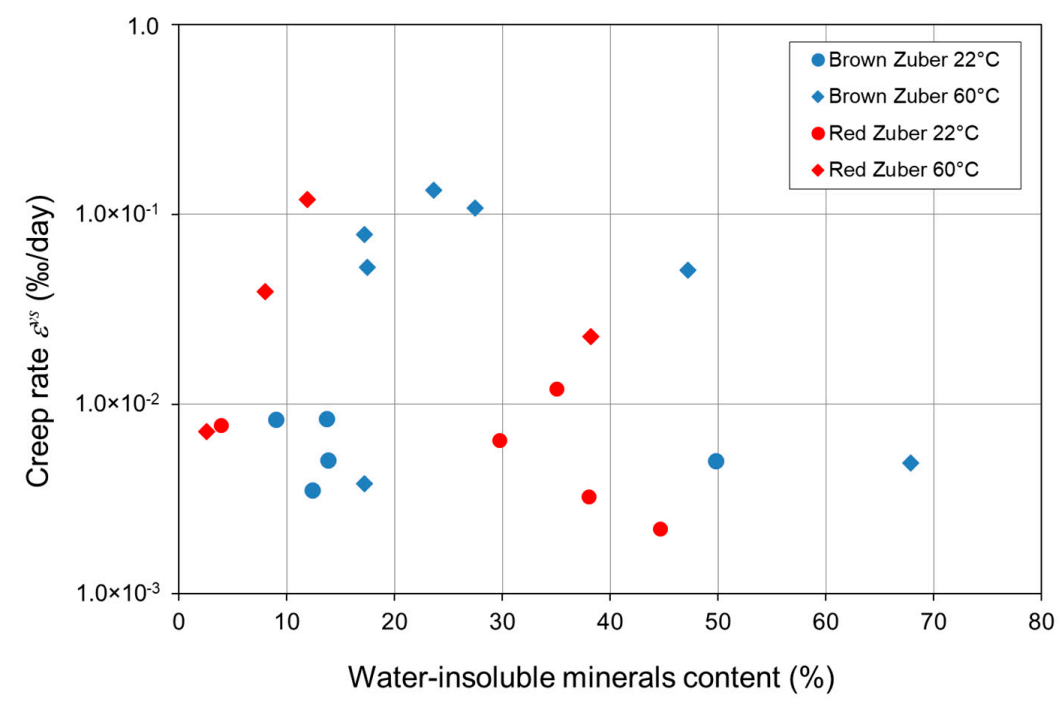

Figure 20. Steady-state creep rate of the Brown and Red Zuber unit samples, depending on the water-insoluble minerals content. 
Relaxation is the reverse process of creep and it consists of the reduction of stresses in a sample at a constant strain. The main purpose of the conducted experiments was to estimate the stress values to which relaxation tends and what it depends on. These values can be considered as the limit below which the creep phenomenon does not occur. In both research phases, twenty relaxation tests, in the triaxial stress state, were conducted in total. The confining pressure value was $5 \mathrm{MPa}$ during the tests and the initial axial stress values were $20 \mathrm{MPa}, 25 \mathrm{MPa}$, or $30 \mathrm{MPa}$, with the temperatures of $22^{\circ} \mathrm{C}$, $60^{\circ} \mathrm{C}$, and $90^{\circ} \mathrm{C}$. Selected test results are presented in Figure 21.

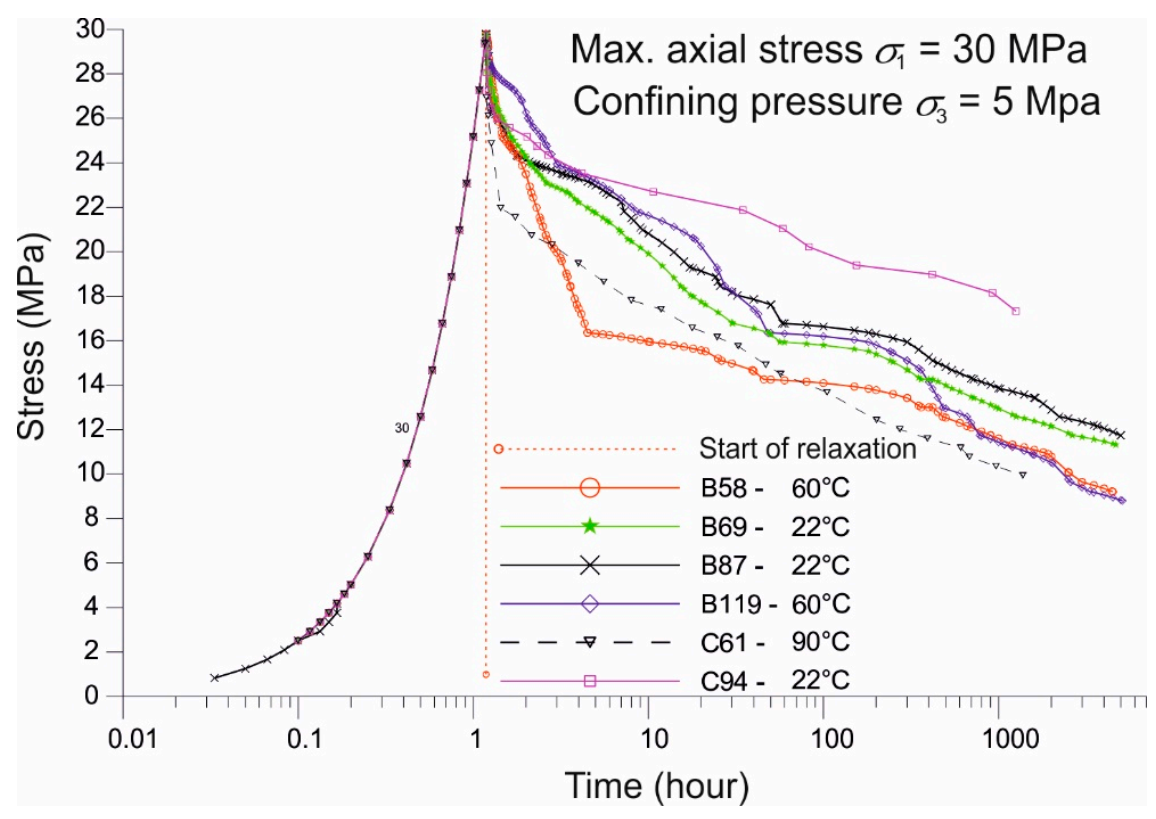

Figure 21. The Brown and Red Zuber unit samples' relaxation curves at the initial axial stress of $30 \mathrm{MPa}$ (according to [62]).

The relaxation limit depends on both initial stresses and temperature. An increase in temperature causes that relaxation tends to achieve a steady state at lower stress conditions. However, the initial stress increase causes that relaxation tends to reach a steady state at higher stress conditions.

The conducted experiments allowed to determine the Norton creep law coefficients, described by the following formula:

$$
\dot{\varepsilon}_{e f}^{v s}=A e^{-\frac{Q}{R T}} \sigma_{e f}^{n}
$$

where:

$Q$-free activation energy $\left(\mathrm{J} \cdot \mathrm{mol}^{-1}\right)$;

$R$-gas constant $8.3144 \mathrm{~J} \cdot \mathrm{mol}^{-1} \cdot \mathrm{K}^{-1}=1.987 \mathrm{cal} \cdot \mathrm{mol}^{-1} \cdot \mathrm{K}^{-1}$;

$T$-temperature (in absolute scale) (K).

The creep law coefficients were determined analyzing individual samples during multi-step creep tests at variable stress and temperature conditions.

The average values of the $A, Q / R$ and $n$ coefficients are presented in Table 3.

Table 3. Average values of the creep law coefficients [62].

\begin{tabular}{cccc}
\hline & $A(\%$ \%odday) & $Q / R(K)$ & $n$ \\
\hline Brown Zuber & 572.4 & 6294.3 & 4.1 \\
Red Zuber & $32,655.1$ & 7351.8 & 3.9 \\
\hline
\end{tabular}

The comparison of the Brown and Red Zuber unit samples' creep rates to those of the fast-creeping salts (BGRa) and slow-creeping salts (BGRb) [63] is presented in Figure 22. 


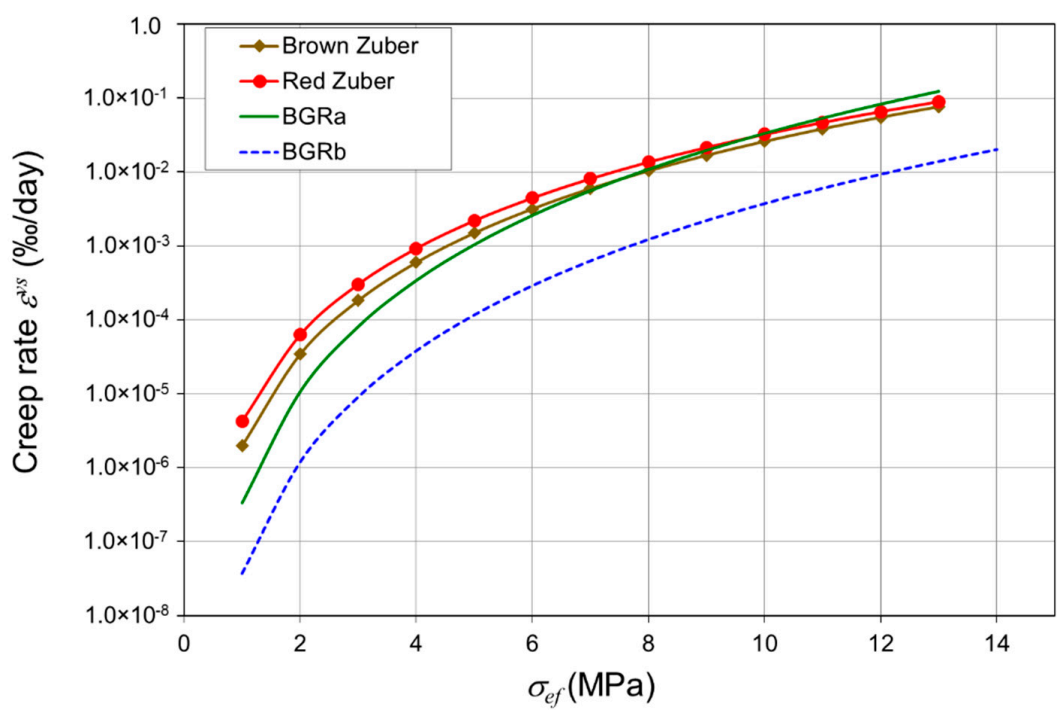

Figure 22. Creep rates of the Brown and Red Zuber unit samples and of the fast-creeping (BGRa) and slow-creeping (BGRb) rock salt samples in the effective stress function at a temperature of $50{ }^{\circ} \mathrm{C}$.

The comparison presented in Figure 22 indicates that both the Brown Zuber and the Red Zuber unit rocks may be classified as fast creeping rocks.

\section{Conclusions}

From the standpoint of the deep geological disposal of radioactive waste, the largest differences between rock salts and zuber rocks are associated with geomechanical properties. The short-time strength of the tested zuber rock samples is diverse and lower than that of rock salt. The zuber rock samples with the highest strength values correspond to the rock salt sample with the lowest strength. Much lower are, however, the deformations at the moment of zuber rock failure. Their average values are three times lower than those of rock salt samples. Those properties, in comparison to the steady-state creep rate being similar to that of rock salt and the unclear influence of water-insoluble minerals content on creep rate, indicate a lower long-term strength of zuber rocks in comparison to that of rock salt.

The changes in zuber rock mass resulted mainly from dehydration during the heating period. Higher water content in samples of the Brown and the Red Zuber unit rocks compared to rock salt may be responsible for enhancement of the creep mechanisms and lead to the decrease in long-term strength.

Consequently, a repository may not be constructed so deeply in zuber rocks as it may be in the case of rock salts. Besides, one should also take into account the necessity to leave larger safety pillars between disposal and functional galleries.

The remaining tested parameters indicated beneficial zuber rock properties from the standpoint of deep geological disposal of SNF and HLW.

The changes in linear dimensions of the Brown and the Red Zuber unit samples observed during sample heating to the temperature of $140{ }^{\circ} \mathrm{C}$ indicated a lack of a clear dependence between the thermal expansion of the samples and their mineral content. That may confirm the assumption that zuber rocks and the accompanying rock salts had been properly heated and compressed even before they were uplifted in the form of a salt dome. It indicates that the temperatures expected to exist in a potential repository, ranging from 100 to $120^{\circ} \mathrm{C}$, close to the radioactive waste containers, should not cause changes or deformations, which would exclude siting of repositories in zuber rocks.

The sorption properties of zuber rocks are beneficial in comparison to those of rock salt. The obtained results demonstrated that the fraction of water-insoluble minerals occurring both in the Brown and Red Zuber unit rocks, in contrast to rock salt, has a high sorption capability to permanently immobilize ${ }^{90} \mathrm{Sr}$ and ${ }^{152,154} \mathrm{Eu}$ radionuclides. 
The research presented above was conducted in laboratory conditions, using rock samples with specific volumes. For that reason, confirmation tests of the results obtained should be carried out in in situ conditions.

Funding: This research was funded by National Centre for Research and Development, grant No. 5 T12B 01425 and the APC was funded by budgetary resources of MEERI PAS.

Conflicts of Interest: The author declares no conflict of interest.

\section{Appendix A}
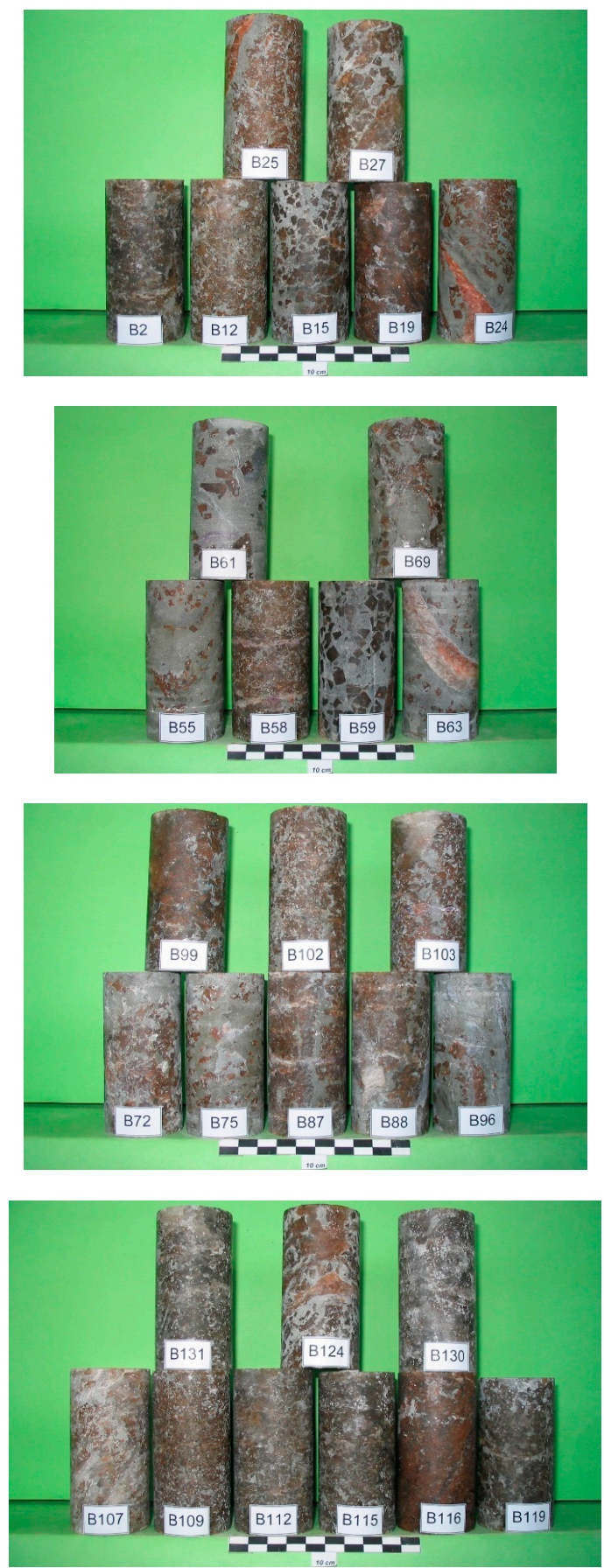

Figure A1. The Brown Zuber unit samples for short-term compression tests at a constant stress rate and for rheological tests. 

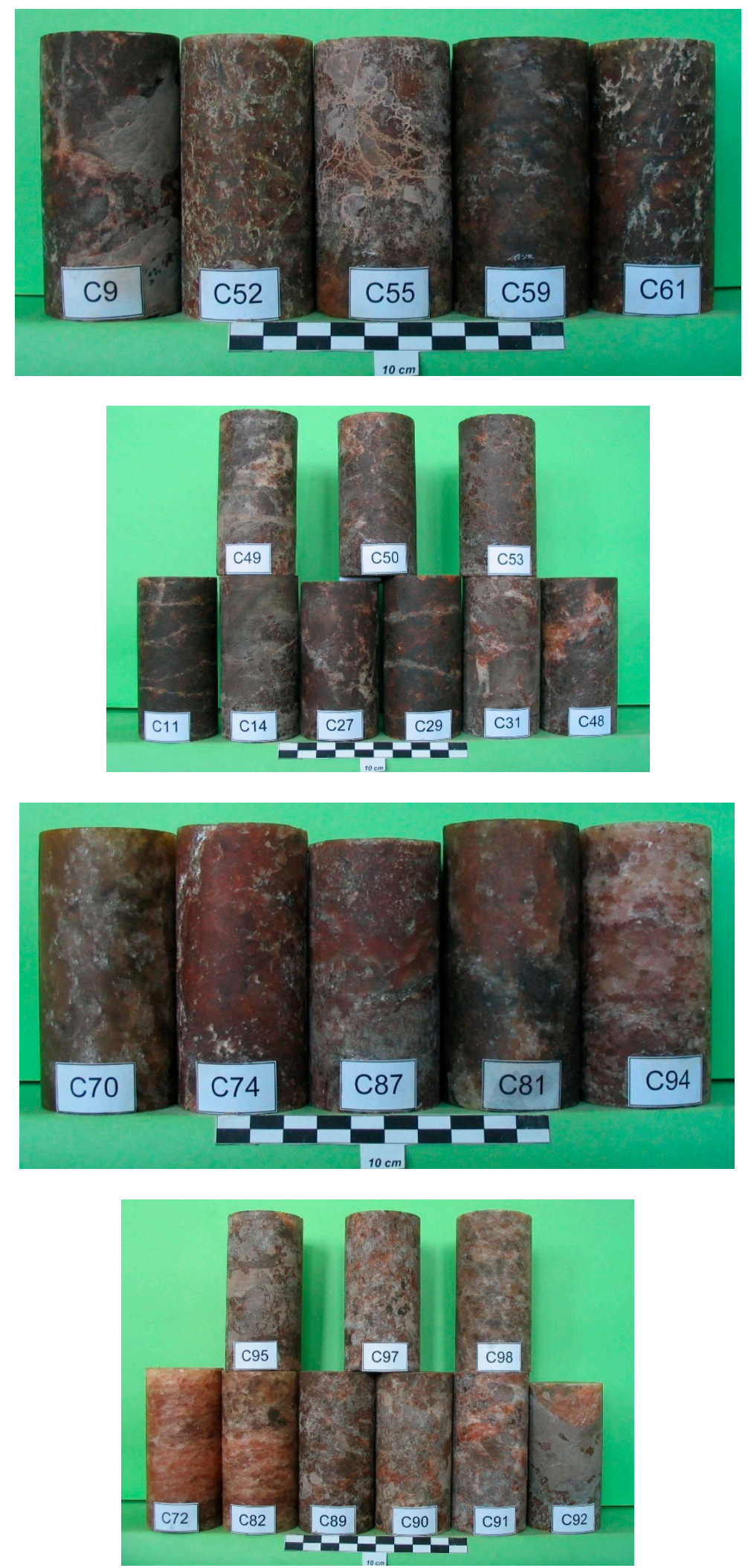

Figure A2. The Red Zuber unit samples for short-term compression tests at a constant stress rate and for rheological tests. 

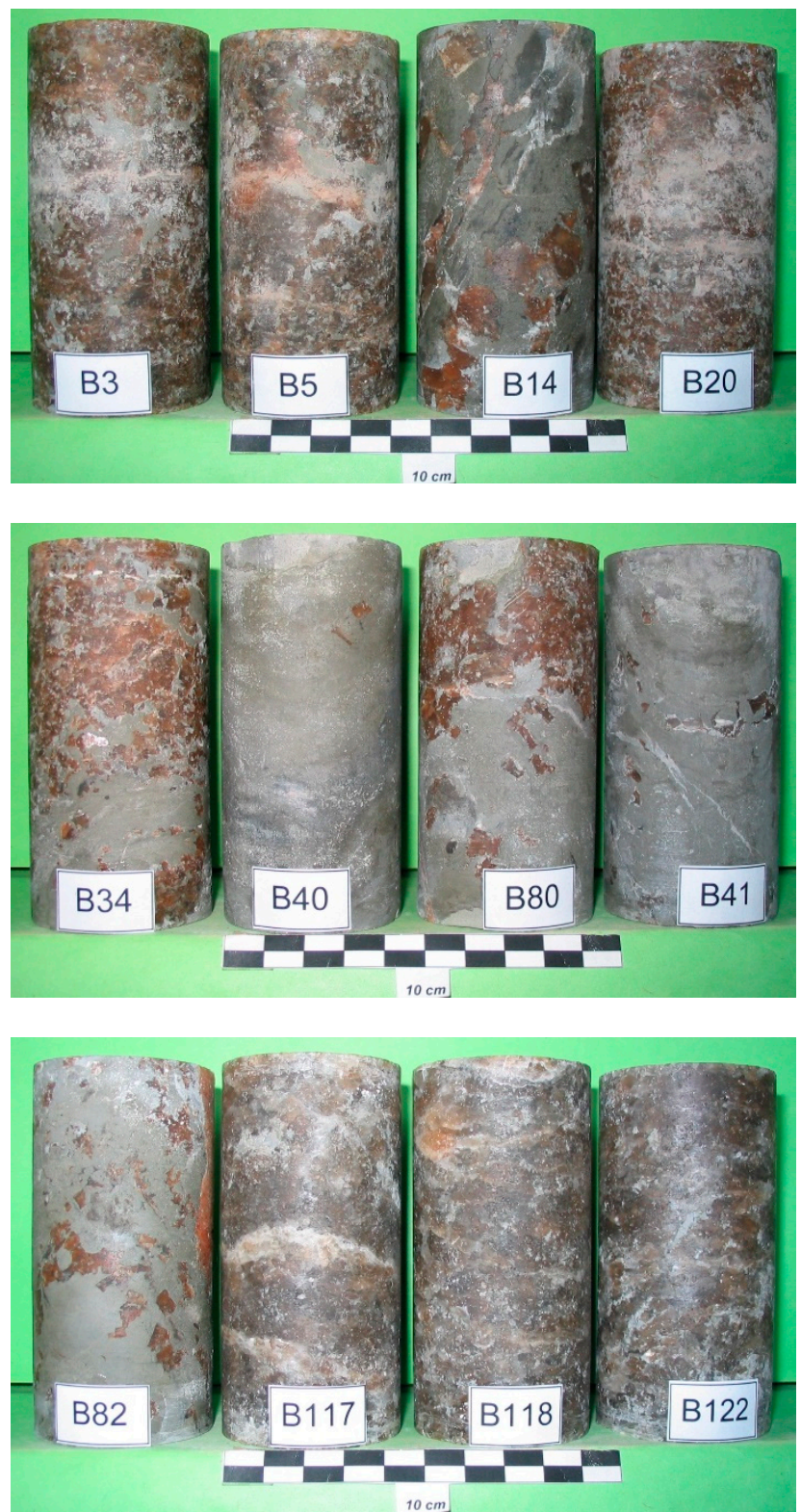

Figure A3. The Brown Zuber unit samples for short-term compression tests at a constant strain rate. 

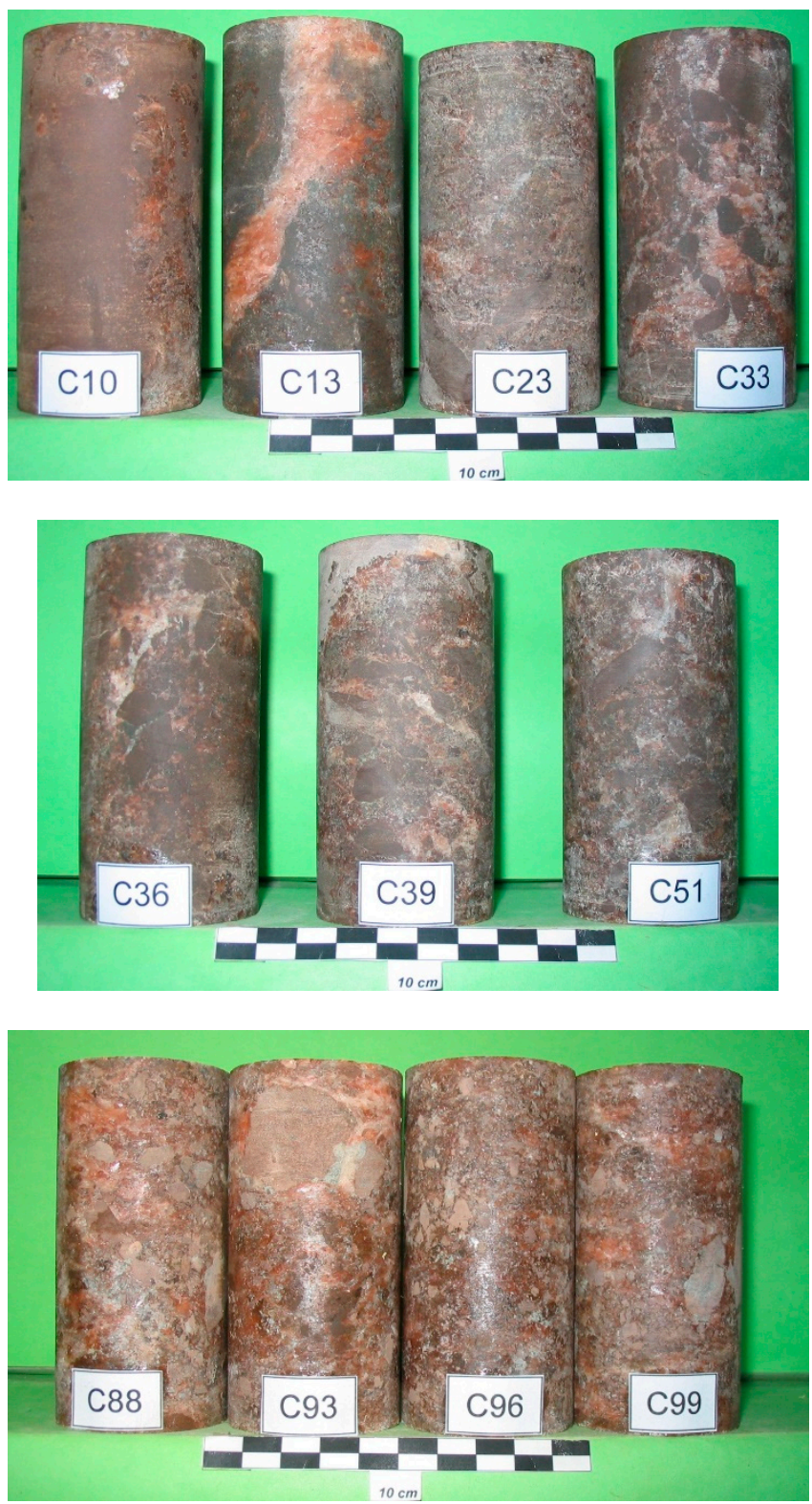

Figure A4. The Red Zuber unit samples for short-term compression tests at a constant strain rate. 
Table A1. Results of short-term compression tests of the Brown and Red Zuber unit samples (according to [57,58,62]).

\begin{tabular}{|c|c|c|c|c|c|c|c|c|c|c|c|c|c|}
\hline \multicolumn{7}{|c|}{ Short-Term Compression Tests at Constant Stress Rate } & \multicolumn{7}{|c|}{ Short-Term Compression Tests at Constant Strain Rate } \\
\hline \multirow[t]{2}{*}{ Sample } & \multirow[t]{2}{*}{$\begin{array}{l}\text { Water-Insoluble } \\
\text { Minerals(\%) }\end{array}$} & \multirow{2}{*}{$\begin{array}{l}\text { Confining } \\
\text { Pressure } \\
\text { (MPa) }\end{array}$} & \multirow{2}{*}{$\begin{array}{l}\text { Maximum } \\
\text { Effective } \\
\text { Stress (MPa) }\end{array}$} & \multirow{2}{*}{$\begin{array}{c}\text { Maximum } \\
\text { Axial Strain } \\
(\%)\end{array}$} & \multicolumn{2}{|c|}{$\begin{array}{l}\text { Young's Modulus } \\
\text { (GPa) }\end{array}$} & \multirow[t]{2}{*}{ Sample } & \multirow[t]{2}{*}{$\begin{array}{l}\text { Water-Insoluble } \\
\text { Minerals (\%) }\end{array}$} & \multirow{2}{*}{$\begin{array}{l}\text { Strain } \\
\text { Rate } \\
\left(\mathrm{s}^{-1}\right)\end{array}$} & \multirow{2}{*}{$\begin{array}{l}\text { Maximum } \\
\text { Effective } \\
\text { Stress (MPa) }\end{array}$} & \multirow{2}{*}{$\begin{array}{c}\text { Maximum } \\
\text { Axial Strain } \\
\text { (\%) }\end{array}$} & \multirow{2}{*}{$\begin{array}{c}\text { Dynamic } \\
\text { Modulus Of } \\
\text { Elasticity (GPa) }\end{array}$} & \multirow[t]{2}{*}{$\begin{array}{l}\text { Poisson's } \\
\text { Ratio (-) }\end{array}$} \\
\hline & & & & & $E_{1}$ & $E_{2}$ & & & & & & & \\
\hline B27 & 38.6 & & 42.1 & 2.2 & 12.0 & 18.8 & B3 & 24.5 & $10^{-4}$ & 50.0 & 9.6 & 43.8 & 0.37 \\
\hline B59 & 42.7 & 2 & 32.5 & 1.57 & 8.7 & 19.2 & B14 & 71.3 & $10^{-5}$ & 31.8 & 1.1 & ** & 0.15 \\
\hline B72 & 12.1 & & 24.7 & 1.74 & * & * & B34 & 44.8 & $10^{-4}$ & 33.0 & 4.0 & 36.2 & 0.12 \\
\hline B25 & 25.5 & & 53.4 & 5.85 & 10.2 & 13.3 & B41 & 79.7 & $10^{-5}$ & 18.1 & 0.6 & $* *$ & 0.11 \\
\hline B63 & 56.6 & 5 & 34.8 & 2.19 & $*$ & $*$ & B80 & 38.7 & $10^{-4}$ & 27.0 & 1.0 & 49.3 & 0.13 \\
\hline B75 & 56.2 & & 37.0 & 1.64 & 10.6 & 19.0 & B82 & 79.9 & $10^{-5}$ & 29.2 & 0.7 & $* *$ & 0.15 \\
\hline B24 & 38.6 & & 57.1 & 3.53 & 18.5 & 24.5 & B117 & 4.3 & $10^{-4}$ & 54.5 & 9.4 & 37.5 & 0.44 \\
\hline B96 & 71.5 & 10 & 52.0 & 1.45 & 13.2 & 29.6 & B118 & 7.3 & $10^{-5}$ & 45.9 & 8.2 & 40.4 & 0.34 \\
\hline B124 & 31.9 & & 70.7 & 7.57 & 18.9 & 21.0 & B122 & 9.0 & $5 \times 10^{-6}$ & 39.9 & 6.1 & 33.4 & 0.30 \\
\hline C9 & 28.8 & & 38.6 & 2.38 & 11.8 & 19.7 & $\mathrm{C} 10$ & 65.1 & $10^{-4}$ & 37.2 & 0.9 & 54.6 & 0.09 \\
\hline C89 & 24.9 & 2 & 47.7 & 3.13 & 11.9 & 13.7 & $\mathrm{C} 13$ & 47.7 & $10^{-5}$ & 39.7 & 4.1 & 34.3 & 0.23 \\
\hline C92 & 46.7 & & 37.3 & 1.37 & 10.2 & 18.7 & C33 & 46.6 & $10^{-4}$ & 36.4 & 3.8 & 27.3 & 0.09 \\
\hline C14 & 63.0 & & 50.0 & 3.81 & 12.2 & 23.8 & C36 & 46.9 & $10^{-5}$ & 27.6 & 3.8 & 30.4 & 0.14 \\
\hline C29 & 42.7 & 5 & 56.4 & 3.45 & 15.7 & 23.6 & $\mathrm{C} 23$ & 38.1 & $10^{-4}$ & 36.2 & 3.2 & 38.6 & 0.11 \\
\hline C90 & 45.6 & & 48.4 & 4.27 & 10.1 & 15.2 & C51 & 32.2 & $10^{-5}$ & 34.5 & 5.4 & $* *$ & 0.17 \\
\hline C48 & 38.0 & & 67.5 & 5.98 & $*$ & $*$ & C99 & 23.4 & $10^{-4}$ & 35.9 & 2.8 & 32.6 & 0.21 \\
\hline C50 & 30.9 & 10 & 61.1 & 5.24 & 13.8 & 18.4 & C93 & 21.9 & $10^{-5}$ & 40.4 & 6.7 & 26.8 & 0.11 \\
\hline C97 & 39.9 & & 77.6 & 6.30 & 15.9 & 24.4 & C96 & 24.6 & $5 \times 10^{-6}$ & 45.9 & 7.8 & 37.1 & 0.21 \\
\hline
\end{tabular}

*-no unloading cycle performed; **-ultrasonic wave velocity could not be determined.

Table A2. Load-thermal conditions and the results of the rheological tests-the Brown Zuber unit samples (according to [58,62]).

\begin{tabular}{|c|c|c|c|c|c|c|c|c|c|c|c|}
\hline Sample & $\begin{array}{c}\text { Water-Insoluble } \\
\text { Minerals (\%) }\end{array}$ & $\begin{array}{l}\text { No. of Test } \\
\text { Stages }\end{array}$ & $\begin{array}{c}\text { Effective Stress } \\
\sigma_{e f}(\mathrm{MPa})\end{array}$ & Temp. $\left({ }^{\circ} \mathrm{C}\right)$ & $\begin{array}{l}\text { Time } \\
\text { (days) }\end{array}$ & $\begin{array}{c}\text { Stationary Creep } \\
\text { Rate (\%o/day) }\end{array}$ & $\begin{array}{c}\text { Transient } \\
\text { Creep (\%o) }\end{array}$ & $\begin{array}{c}\text { Primary } \\
\text { Strain }(\% o)\end{array}$ & $A$ & $Q / R$ & $n$ \\
\hline \multirow{5}{*}{ B2 } & \multirow{5}{*}{27.5} & \multirow{5}{*}{5} & 10 & 60 & $0-92$ & 0.108 & \multirow[t]{5}{*}{1.01} & \multirow[t]{5}{*}{4.41} & 649.2 & & \\
\hline & & & 10 & 35 & $92-371$ & 0.0361 & & & 1006.4 & 4495.7 & \\
\hline & & & 7.5 & 35 & $371-511$ & 0.0095 & & & 947.2 & & 4.64 \\
\hline & & & 7.5 & 50 & $511-700$ & 0.0158 & & & 609.9 & 3374.0 & \\
\hline & & & 15 & 50 & $700-757$ & 0.590 & & & 1056.5 & & 5.22 \\
\hline \multirow{2}{*}{ B12 } & \multirow{2}{*}{17.2} & \multirow{2}{*}{2} & 10 & 60 & $0-87$ & 0.0785 & 3.85 & \multirow[t]{2}{*}{5.96} & 471.9 & & \\
\hline & & & 10 & 75 & $87-150$ & 0.218 & 5.71 & & 580.2 & 7890.9 & \\
\hline
\end{tabular}


Table A2. Cont.

\begin{tabular}{|c|c|c|c|c|c|c|c|c|c|c|c|}
\hline Sample & $\begin{array}{c}\text { Water-Insoluble } \\
\text { Minerals (\%) }\end{array}$ & $\begin{array}{l}\text { No. of Test } \\
\text { Stages }\end{array}$ & $\begin{array}{c}\text { Effective Stress } \\
\sigma_{e f}(\mathrm{MPa})\end{array}$ & Temp. $\left({ }^{\circ} \mathrm{C}\right)$ & $\begin{array}{c}\text { Time } \\
\text { (days) }\end{array}$ & $\begin{array}{c}\text { Stationary Creep } \\
\text { Rate (\%o/day) }\end{array}$ & $\begin{array}{c}\text { Transient } \\
\text { Creep (\%o) }\end{array}$ & $\begin{array}{c}\text { Primary } \\
\text { Strain }(\% o)\end{array}$ & $A$ & $Q / R$ & $n$ \\
\hline \multirow{2}{*}{ B15 } & \multirow{2}{*}{49.8} & \multirow{2}{*}{2} & 10 & 22 & $0-93$ & 0.00503 & \multirow[t]{2}{*}{0.79} & \multirow[t]{2}{*}{3.38} & 345.1 & & \multirow[b]{2}{*}{6.39} \\
\hline & & & 7.5 & 22 & $93-156$ & 0.0008 & & & 196.3 & & \\
\hline \multirow{4}{*}{ B19 } & \multirow{4}{*}{23.6} & \multirow{4}{*}{4} & 10 & 60 & $0-87$ & 0.1338 & \multirow[t]{4}{*}{0.79} & \multirow[t]{4}{*}{3.71} & 804.3 & & \multirow{4}{*}{5.62} \\
\hline & & & 10 & 90 & $87-100$ & 1.355 & & & 1707.9 & 9328.7 & \\
\hline & & & 7.5 & 90 & $100-175$ & 0.2693 & & & 1214.1 & & \\
\hline & & & 7.5 & 60 & $175-203$ & 0.0345 & & & 741.7 & 8279.7 & \\
\hline B55 & 67.9 & 1 & 10 & 60 & $0-142$ & 0.00488 & 4.54 & 5.81 & 29.3 & - & - \\
\hline \multirow{5}{*}{ B88 } & \multirow{5}{*}{47.2} & \multirow{5}{*}{5} & 10 & 60 & 0-92 & 0.0508 & \multirow[t]{5}{*}{2.69} & \multirow[t]{5}{*}{5.21} & 305.4 & & \multirow{5}{*}{5.01} \\
\hline & & & 10 & 35 & $92-371$ & 0.01345 & & & 375.0 & 5452.0 & \\
\hline & & & 12.5 & 35 & $371-511$ & 0.0413 & & & 428.4 & & \\
\hline & & & 12.5 & 50 & $511-688$ & 0.0777 & & & 312.0 & 4191.5 & \\
\hline & & & 15 & 50 & 688-889 & 0.2288 & & & 409.7 & & \\
\hline \multirow{2}{*}{ B99 } & \multirow{2}{*}{13.7} & \multirow{2}{*}{2} & 10 & 22 & $0-93$ & 0.0084 & \multirow[t]{2}{*}{0.88} & \multirow[t]{2}{*}{3.31} & 576.3 & & \multirow[b]{2}{*}{7.13} \\
\hline & & & 7.5 & 22 & $93-156$ & 0.00108 & & & 265.0 & & \\
\hline \multirow{4}{*}{ B109 } & \multirow{4}{*}{17.5} & \multirow{4}{*}{4} & 10 & 60 & $0-87$ & 0.0526 & \multirow[t]{4}{*}{2.40} & \multirow[t]{4}{*}{5.76} & 316.2 & & \\
\hline & & & 10 & 90 & $87-116$ & 0.5745 & & & 724.1 & 9633.2 & \\
\hline & & & 7.5 & 90 & $116-175$ & 0.398 & & & 1794.3 & & 1.28 \\
\hline & & & 7.5 & 60 & $175-203$ & 0.0881 & & & 1894.1 & 6076.1 & \\
\hline & & & 10 & 22 & $0-93$ & 0.00352 & 1.74 & 4.39 & 241.5 & & \\
\hline B112 & 12.4 & 2 & 20 & 22 & 93-156 & 0.0321 & 3.63 & & 102.2 & & 3.19 \\
\hline & & & 10 & 22 & $0-93$ & 0.00505 & 1.37 & 3.45 & 346.5 & & \\
\hline B116 & 13.8 & 2 & 15 & 22 & $93-211$ & 0.0110 & 3.63 & & 125.2 & & 1.92 \\
\hline & & & 10 & 22 & $0-93$ & 0.00828 & 2.22 & 4.72 & 568.1 & & \\
\hline B130 & 9.0 & 2 & 15 & 22 & $93-211$ & 0.0223 & 6.56 & & 253.9 & & 2.44 \\
\hline & & & 10 & 60 & $0-87$ & 0.00382 & 1.93 & 6.22 & 23.0 & & \\
\hline B131 & 17.2 & 3 & 10 & 90 & $87-155$ & 0.0112 & 2.23 & & 14.1 & 4221.1 & \\
\hline & & & 12.5 & 90 & 155-203 & 0.0125 & 2.46 & & 28.0 & & 0.62 \\
\hline
\end{tabular}


Table A3. Load-thermal conditions and the results of the rheological tests—-the Red Zuber unit samples (according to [58,62]).

\begin{tabular}{|c|c|c|c|c|c|c|c|c|c|c|c|}
\hline Sample & $\begin{array}{c}\text { Water-Insoluble } \\
\text { Minerals (\%) }\end{array}$ & $\begin{array}{l}\text { No. of Test } \\
\text { Stages }\end{array}$ & $\begin{array}{c}\text { Effective Stress } \\
\sigma_{e f}(\mathrm{MPa})\end{array}$ & Temp. $\left({ }^{\circ} \mathrm{C}\right)$ & $\begin{array}{c}\text { Time } \\
\text { (days) }\end{array}$ & $\begin{array}{c}\text { Stationary Creep } \\
\text { Rate (\%o/day) }\end{array}$ & $\begin{array}{c}\text { Transient } \\
\text { Creep (\%o) }\end{array}$ & $\begin{array}{c}\text { Primary } \\
\text { Strain }(\% \circ)\end{array}$ & $A$ & $Q / R$ & $n$ \\
\hline C11 & 26.3 & 1 & 12.5 & 75 & $0-114$ & 0.0028 & 3.17 & 6.33 & 232.3 & & \\
\hline \multirow{3}{*}{ C27 } & \multirow{3}{*}{64.1} & \multirow{3}{*}{3} & 12.5 & 90 & $0-5$ & 4.31 * & & \multirow{3}{*}{6.09} & $11,591.8$ & & \\
\hline & & & 7.5 & 90 & 5-17 & $0.893^{* *}$ & & & 7886.9 & & 3.08 \\
\hline & & & 7.5 & 60 & $17-53$ & $0.367^{* *}$ & & & $53,059.6$ & 3583.0 & \\
\hline \multirow[b]{2}{*}{ C53 } & \multirow{2}{*}{38.2} & \multirow[b]{2}{*}{2} & 10 & 60 & $0-85$ & 0.0227 & 8.41 & \multirow[b]{2}{*}{12.38} & $18,086.2$ & \multirow[b]{2}{*}{4376.7} & \\
\hline & & & 10 & 75 & $85-148$ & 0.04 & 8.64 & & $61,125.3$ & & \\
\hline \multirow{2}{*}{ C55 } & \multirow{2}{*}{27.4} & \multirow[b]{2}{*}{2} & 7.5 & 90 & $0-72$ & 0.211 & 4.03 & \multirow{2}{*}{5.58} & $11,133.0$ & \multirow[b]{2}{*}{$11,688.4$} & \\
\hline & & & 7.5 & 60 & $72-127$ & 0.0116 & & & $56,856.8$ & & \\
\hline \multirow{2}{*}{ C59 } & \multirow{2}{*}{11.9} & \multirow{2}{*}{2} & 10 & 60 & $0-54$ & 0.1197 & 2.34 & \multirow{2}{*}{4.65} & $47,418.0$ & \multirow[b]{2}{*}{$13,079.5$} & \\
\hline & & & 10 & 30 & 54-110 & 0.00245 & & & $18,559.8$ & & \\
\hline \multirow{4}{*}{ C70 } & \multirow{4}{*}{29.7} & \multirow{4}{*}{4} & 10 & 22 & $0-371$ & 0.00648 & 3.39 & \multirow{4}{*}{3.74} & $14,307.2$ & & \\
\hline & & & 7.5 & 22 & 371-511 & 0.00177 & & & $67,912.3$ & & 4.51 \\
\hline & & & 15 & 22 & $511-700$ & 0.0102 & 4.76 & & $32,388.7$ & & 2.53 \\
\hline & & & 17.5 & 22 & $700-884$ & 0.0143 & 9.03 & & $19,391.0$ & & 2.19 \\
\hline \multirow{2}{*}{ C72 } & \multirow{2}{*}{3.9} & \multirow{2}{*}{2} & 10 & 22 & 0-93 & 0.00774 & 4.6 & \multirow{2}{*}{11.64} & $31,451.1$ & & \\
\hline & & & 15 & 22 & 93-181 & 0.0178 & 5.9 & & $50,766.5$ & & 2.05 \\
\hline \multirow{4}{*}{ C74 } & & & 10 & 22 & $0-371$ & 0.00221 & 3.97 & & $34,817.6$ & & \\
\hline & & & 12.5 & 22 & $371-511$ & 0.00852 & 4.28 & & 3661.4 & & 6.05 \\
\hline & 44.6 & 4 & 15 & 22 & $511-700$ & 0.0279 & 6.72 & 7.7 & 1927.2 & & 6.51 \\
\hline & & & 17.5 & 22 & 700-885 & 0.0348 & 6.89 & & $19,402.9$ & & 1.43 \\
\hline & & & 10 & 60 & $0-87$ & 0.00717 & 2.13 & & $106,167.8$ & & \\
\hline $\mathrm{C} 82$ & 2.6 & 3 & 10 & 90 & $87-176$ & 0.0234 & 2.92 & 16.74 & $46,614.3$ & 4766.0 & \\
\hline & & & 10 & 40 & 176-204 & 0.00927 & & & $28,516.1$ & 2104.1 & \\
\hline & & & 10 & 22 & 0-93 & 0.0121 & 4.24 & & $24,434.0$ & & \\
\hline C91 & 35.0 & 2 & 7.5 & 22 & 93-156 & 0.00174 & & $7.4 b$ & $20,068.7$ & & 6.74 \\
\hline & & & 10 & 22 & 0-93 & 0.00325 & 4.62 & & $61,515.1$ & & \\
\hline C95 & 38.8 & 2 & 20 & 22 & 93-211 & 0.041 & 8.67 & 6.04 & 232.3 & & 3.66 \\
\hline C98 & 8.0 & 2 & 10 & 60 & $0-87$ & 0.0393 & 1.73 & 7.96 & $11,591.8$ & & \\
\hline$c>0$ & 0.0 & 2 & 10 & 90 & $87-150$ & 0.7469 & & 1.90 & 7886.9 & $11,865.1$ & \\
\hline
\end{tabular}

* No stationary creep phase was recorded during the test and the value given relates to the pre-destructive phase. ${ }^{* *}$ Stationary creep rate increased due to sample failure during the first stage of the experiment. 


\section{References}

1. Suman, S. Hybrid nuclear-renewable energy systems: A review. J. Clean. Prod. 2018, 181, 166-177. [CrossRef]

2. Gralla, F.; John, B.; Abson, D.J.; Møller, A.P.; Bickel, M.; Lang, D.J.; von Wehrden, H. The role of sustainability in nuclear energy plans-What do national energy strategies tell us? Energy Res. Soc. Sci. 2016, 22, 94-106. [CrossRef]

3. Toth, F.L. Nuclear energy and sustainable development. Energy Policy 2014, 74, S1-S4. [CrossRef]

4. Electricity Production from Nuclear Sources. Available online: https://data.worldbank.org/indicator/EG.ELC. NUCL.ZS (accessed on 19 February 2020).

5. IAEA PRIS Power Reactor Information System. Available online: https://pris.iaea.org/PRIS/home.aspx (accessed on 19 February 2020).

6. International Atomic Energy Agency Energy, Electricity and Nuclear Power Estimates for the Period up to 2050; Reference Data Series No. 1; IAEA: Viena, Austria, 2019.

7. Gralla, F.; Abson, D.J.; Møller, A.P.; Lang, D.J.; von Wehrden, H. Energy transitions and national development indicators: A global review of nuclear energy production. Renew. Sustain. Energy Rev. 2017, 70, 1251-1265. [CrossRef]

8. IAEA. International Atomic Energy Agency Classification of Radioactive Waste; IAEA Safety Standards General Safety Guide No.GSG-1; IAEA: Viena, Austria, 2009; p. 51.

9. Vance, E.R.; Begg, B.D.; Gregg, D.J. Immobilization of high-level radioactive waste and used nuclear fuel for safe disposal in geological repository systems. In Geological Repository Systems for Safe Disposal of Spent Nuclear Fuels and Radioactive Waste; Apted, M.J., Ahn, J., Eds.; Woodhead Publishing: Cambridge, UK, 2017; pp. 269-295, ISBN 9781845699789.

10. International Atomic Energy Agency. Options for Management of Spent Nuclear Fuel and Radioactive Waste for Countries Developing New Nuclear Power Programmes; IAEA: Viena, Austria, 2018.

11. Spykman, G. Dry storage of spent nuclear fuel and high active waste in Germany-Current situation and technical aspects on inventories integrity for a prolonged storage time. Nucl. Eng. Technol. 2018, 50, 313-317. [CrossRef]

12. Chu, M.S.Y. Spent nuclear fuel recycling practices, technologies and impact on geological repository systems. In Geological Repository Systems for Safe Disposal of Spent Nuclear Fuels and Radioactive Waste; Ahn, J., Apted, M.J., Eds.; Woodhead Publishing: Cambridge, UK, 2010; pp. 29-42, ISBN 9781845695422.

13. IAEA. International Atomic Energy Agency Selection of Away-From-Reactor Facilities for Spent Fuel Storage; IAEA-TECDOC-1558; IAEA: Viena, Austria, 2007; pp. 1-119.

14. IAEA. International Atomic Energy Agency Disposal of Radioactive Waste; IAEA Safety Standards, Specific Safety Requirements No. SSR-5; IAEA: Viena, Austria, 2011; pp. 1-65.

15. Apted, M.; Ahn, J. Multiple-barrier geological repository design and operation strategies for safe disposal of radioactive materials. In Geological Repository Systems for Safe Disposal of Spent Nuclear Fuels and Radioactive Waste; Ahn, J., Apted, M.J., Eds.; Woodhead Publishing: Cambridge, UK, 2010; pp. 3-28, ISBN 9781845695422.

16. Rempe, N.T. Permanent underground repositories for radioactive waste. Prog. Nucl. Energy 2007, 49, 365-374. [CrossRef]

17. Faybishenko, B.; Birkholzer, J.; Sassani, D.; Swift, P.N. International Approaches for Deep Geological Disposal of Nuclear Waste: Geological Challenges in Fifth Worldwide Review International Approaches for Deep Geological Disposal of Nuclear Waste: Geological Challenges in Radioactive Waste Isolation Fifth Wo; Lawrence Berkeley National Laboratory: Berkeley, CA, USA, 2016.

18. Witherspoon, P.A.; DeMarsily, G. Introduction. In Proceedings of the Geological Problems in Radioactive Waste Isolation: A World Wide Review; Witherspoon, P.A., Ed.; Lawrence Berkeley National Laboratory: Berkeley, CA, USA, 1991.

19. Langer, M.; Schneider, H.; Kuhn, K. The Salt Dome of Gorleben Target Site for the German Radioactive Waste Repository. In Proceedings of the Geological Problems in Radioactive Waste Isolation: A World Wide Review; Witherspoon, P.A., Ed.; Lawrence Berkeley National Laboratory: Berkeley, CA, USA, 1991.

20. Von Berlepsch, T. Salt repository systems: Design development approach the example of the Gorleben salt dome. In Geological Repository Systems for Safe Disposal of Spent Nuclear Fuels and Radioactive Waste; Apted, M.J., Ahn, J., Eds.; Woodhead Publishing: Cambridge, UK, 2017; pp. 145-162, ISBN 9780081006429. 
21. Delay, J. Clay geological repository systems: Characterisation and site surveying technologies and techniques. In Geological Repository Systems for Safe Disposal of Spent Nuclear Fuels and Radioactive Waste; Ahn, J., Apted, M.J., Eds.; Woodhead Publishing: Cambridge, UK, 2010; pp. 153-187, ISBN 9781845695422.

22. Hooper, A.J. Crystalline geological repository systems: Characterisation, site surveying and construction technologies and techniques. In Geological Repository Systems for Safe Disposal of Spent Nuclear Fuels and Radioactive Waste; Ahn, J., Apted, M.J., Eds.; Woodhead Publishing: Cambridge, UK, 2010; pp. 121-152, ISBN 9781845695422.

23. Blechschmidt, I.; Vomvoris, S. Underground research facilities and rock laboratories for the development of geological disposal concepts and repository systems. In Geological Repository Systems for Safe Disposal of Spent Nuclear Fuels and Radioactive Waste; Ahn, J., Apted, M.J., Eds.; Woodhead Publishing: Cambridge, UK, 2010; pp. 82-118, ISBN 9781845695422.

24. Blechschmidt, I.; Vomvoris, S. Relevance of underground rock laboratories for deep geological repository programs. In Geological Repository Systems for Safe Disposal of Spent Nuclear Fuels and Radioactive Waste; Ahn, J., Apted, M., Eds.; Woodhead Publishing: Cambridge, UK, 2017; pp. 113-142, ISBN 9780081006429.

25. Gillhaus, A. Natural Gas Storage in Salt Caverns-Present Status, Developments and Future Trends in Europe. In Proceedings of the SMRI Spring 2007 Conference, Basel, Switzerland, 29 April-2 May 2017; Solution Mining Reserch Institute: Clarks Summit, PA, USA, 2007; pp. 1-19.

26. Tarkowski, R. Underground hydrogen storage: Characteristics and prospects. Renew. Sustain. Energy Rev. 2019, 105, 86-94. [CrossRef]

27. Crotogino, F.; Huebner, S. Energy Storage in Salt Caverns. Developments and Concrete Projects for Adiabatic Compressed Air and for Hydrogen Storage. In Proceedings of the SMRI Spring 2008 Technical Conference, Porto, Portugal, 27-30 April 2008; Solution Mining Reserch Institute: Clarks Summit, PA, USA, 2008; pp. 1-12.

28. Ślizowski, J.; Pilecki, Z.; Urbańczyk, K.; Pilecka, E.; Lankof, L.; Czarny, R. Site assessment for astroparticle detector location in evaporites of the Polkowice-Sieroszowice copper ore mine, Poland. Adv. High Energy Phys. 2013, 2013, 461764. [CrossRef]

29. U.S. Department of Energy. Final Environmental Assessment for Conducting Astrophysics and Other Basic Science Experiments at the WIPP Site; DOE/EA-1340; DoE: Carlsbad, CA, USA, 2001.

30. U.S. Department of Energy. Pioneering Nuclear Waste Disposal; DOE/CAO-00-3124; U.S. Department of Energy: Carlsbad, CA, USA, 2000.

31. Ślizowski, K.; Lankof, L. Geologiczne uwarunkowania skladowania wysokoaktywnych odpadów promieniotwórczych w złozach soli w polsce. Prz. Geol. 2009, 57, 829-838.

32. Wagner, R. Stratygrafia Osadów i Rozwój Basenu Cechsztyńskiego na Niżu Polskim; Wydawnictwo PIG: Warsaw, Poland, 1994; Volume 146.

33. Wagner, R.; Peryt, T.M.; Geologicmy, P.; Mineralnych, G.S.; Geologiczny, P. Possibility of sequence stratigraphic subdivision of the Zechstein in the Polish Basin. Geol. Quart. 1997, 41, 457-474.

34. Wachowiak, J.; Natkaniec-Nowak, L.; Smoliński, W. Mineralogical and petrographic characteristics of Brown Zuber (Na3t) deposits from the borehole M-34 of the Mogilno Salt Dome. Przeglad Solny 2014, 10, 25-38.

35. Natkaniec-Nowak, L.; Wachowiak, J.; Stach, P. Mineralogical and petrological characteristics of Red Zuber (Na4t) deposits from the borehole M-34 of the Mogilno Salt Dome. Przeglad Solny 2014, 10, 13-24.

36. Ślizowski, J.; Lankof, L. Conceptual model of an underground radioactive waste repository in rock-salt and clay formations in Poland. Gospod. Surowcami Miner. 2000, 16, 75-87.

37. Lankof, L.; Ślizowski, J.; Serbin, K. The concept of SN fuel and HLW disposal in rock salt in Poland. In Proceedings of the 6th US/German Workshop on Salt Repository Research, Design, and Operation, Dresden, Germany, 7-9 September 2015; Hansen, F.D., Steiniger, W., Bollingerfehr, W., Eds.; Sandia National Laboratories: Albuquerque, NM, USA, 2016.

38. Czapowski, G.; Langer-Kuźniarowa, A.; Tomassi-Morawiec, H. Characteristics and genesis of mixed salt-clay facies from the Upper Permian of Poland. In Proceedings of the Abstracts of 21st IAS Meeting of Sedimentology, Davos, Switzerland, 3-5 September 2001; p. 161.

39. Tomassi-Morawiec, H.; Wachowiak, J.; Czapowski, G. Geochemia i wykształcenie skał zubrowych górnego permu (cechsztyn) z obszaru Polski Comparative Geochemistry and Development of the Upper Permian (Zechstein) Zuber Rocks from Poland. Biul. Państwowego Inst. Geol. 2019, 477, 69-122. 
40. Onneken, J.; Schramm, M.; Hammer, J. Mineralogy and geochemistry of the tonmittelsalz (z3TM) and tonbrockensalz (z4TS) as "zuber" equivalents in the German Zechstein (upper Permian). Geol. Q. 2018, 62, 896-916. [CrossRef]

41. Lankof, L. Analiza Odkształcalności i Utraty Masy Zubrów Brunatnych w Aspekcie Składowania Odpadów Promieniotwórczych w Środkowopolskich Wysadach Solnych; Wydawnictwo IGSMiE PAN: Kraków, Poland, 2010; ISBN 978-83-60195-93-2.

42. Zhou, Y.X.; Xia, K.; Li, X.B.; Li, H.B.; Ma, G.W.; Zhao, J.; Zhou, Z.L.; Dai, F. Suggested Methods for Determining the Dynamic Strength Parameters and Mode-I Fracture Toughness of Rock Materials. In The ISRM Suggested Methods for Rock Characterization, Testing and Monitoring: 2007-2014; Ulusay, R., Ed.; Springer International Publishing: Cham, Switzerland, 2015; pp. 35-44, ISBN 978-3-319-07713-0.

43. Aydan, O.; Ito, T.; Ozbay, U.; Kwasniewski, M.; Shariar, K.; Okuno, T.; Ozgenoglu, A.; Malan, D.F.; Okada, T. ISRM Suggested Methods for Determining the Creep Characteristics of Rock. In The ISRM Suggested Methods for Rock Characterization, Testing and Monitoring: 2007-2014; Ulusay, R., Ed.; Springer International Publishing: Basel, Switzerland, 2015; pp. 115-130, ISBN 978-3-319-07712-3.

44. Aydin, A. Upgraded ISRM Suggested Method for Determining Sound Velocity by Ultrasonic Pulse Transmission Technique. In The ISRM Suggested Methods for Rock Characterization, Testing and Monitoring: 2007-2014; Ulusay, R., Ed.; Springer International Publishing: Cham, Switzerland, 2015; pp. 95-100, ISBN 978-3-319-07712-3.

45. Bzowska, G.; Janeczek, J. Badania mineralogiczne minerałów niesolnych ze szczególnym uwzględnieniem minerałów ilastych. In Badania Laboratoryjne Zubrów (Iłowców Solnych) dla Oceny Możliwości Składowania Odpadów Promieniotwórczych w Polskich Wysadach Solnych; Ślizowski, K., Ed.; Wydawnictwo IGSMiE PAN: Krakow, Poland, 2005; pp. 37-42, ISBN 83-89174-04-9.

46. Pawlikowski, M.; Ślizowski, K. Badanie rozszerzalności termicznej oraz zmian masy zubrów w trakcie wygrzewania. In Badania Laboratoryjne Zubrów (Iłowców Solnych) dla Oceny Możliwości Składowania Odpadów Promieniotwórczych w Polskich Wysadach Solnych; Ślizowski, K., Ed.; Wydawnictwo IGSMiE PAN: Kraków, Poland, 2005; pp. 21-36, ISBN 83-89174-04-9.

47. De Las Cuevas, C.; Pueyo, J.J. The influence of mineralogy and texture in the water content of rock salt formations. Its implication in radioactive waste disposal. Appl. Geochem. 1995, 10, 317-327. [CrossRef]

48. Schmatz, J.; Urai, J.L. The interaction of migrating grain boundaries and fluid inclusions in naturally deformed quartz: A case study of a folded and partly recrystallized quartz vein from the Hunsrück Slate, Germany. J. Struct. Geol. 2011, 33, 468-480. [CrossRef]

49. Závada, P.; Desbois, G.; Urai, J.L.; Schulmann, K.; Rahmati, M.; Lexa, O.; Wollenberg, U. Impact of solid second phases on deformation mechanisms of naturally deformed salt rocks (Kuh-e-Namak, Dashti, Iran) and rheological stratification of the Hormuz Salt Formation. J. Struct. Geol. 2015, 74, 117-144. [CrossRef]

50. Shao, H.; Wang, Y.; Kolditz, O.; Nagel, T.; Brüning, T. Approaches to multi-scale analyses of mechanically and thermally-driven migration of fluid inclusions in salt rocks. Phys. Chem. Earth 2019, 113, 1-13. [CrossRef]

51. Bauer, S.J.; Song, B.; Sanborn, B. Dynamic compressive strength of rock salts. Int. J. Rock Mech. Min. Sci. 2019, 113, 112-120. [CrossRef]

52. Schenk, O.O.; Urai, J.L. Microstructural evolution and grain boundary structure during static recrystallization in synthetic polycrystals of sodium chloride containing saturated brine. Contrib. Mineral. Petrol. 2004, 146, 671-682. [CrossRef]

53. Warren, J.K. Salt usually seals, but sometimes leaks: Implications for mine and cavern stabilities in the short and long term. Earth-Sci. Rev. 2017, 165, 302-341. [CrossRef]

54. Ślizowski, K.; Gilewicz-Wolter, J.; Kasprzyk, W.; Lankof, L.; Misiek, G.; Ney, R.; Pawlikowski, M.; Pinińska, J.; Przewłocki, K.; Ślizowski, J. Badania Laboratoryjne Kompleksów Zubrów Młodszych Z3 (Brunatnych) i Najmłodszych Z4 (Hematytowych) Cechsztyńskiej Formacji Solonośnej dla Wstępnej Oceny ich Przydatności do Budowy Podziemnego Składowiska Odpadów Promieniotwórczych; unpublished work; Kraków, Poland, 2000.

55. Ślizowski, K.; Gilewicz-Wolter, J.; Kasprzyk, W.; Lankof, L.; Misiek, G.; Ney, R.; Pawlikowski, M.; Przewłocki, K.; Ślizowski, J. Interpretacja Wyników Badań Laboratoryjnych Właściwości Zubrów Brunatnych i Hematytowych dla Oceny ich Przydatności do Składowania Odpadów Promieniotwórczych; unpublished work; Kraków, Poland, 2001. 
56. Gilewicz-Wolter, J.; Dudała, J.; Przewłocki, K.; Ochoński, A. Badania immobilizacji wybranych nuklidów promieniotwórczych w iłowcach solnych. In Badania Laboratoryjne Zubrów (Iłowców Solnych) dla Oceny Możliwości Składowania Odpadów Promieniotwórczych w Polskich Wysadach Solnych; Ślizowski, K., Ed.; Wydawnictwo IGSMiE PAN: Kraków, Poland, 2005; pp. 49-58, ISBN 83-89174-04-9.

57. Pinińska, J.; Łukaszewski, P.; Jarzębski, S. Właściwości deformacyjne i wytrzymałościowe iłowców solnych. In Badania Laboratoryjne Zubrów (Itowców Solnych) dla Oceny Możliwości Składowania Odpadów Promieniotwórczych w Polskich Wysadach Solnych; Ślizowski, K., Ed.; Wydawnictwo IGSMiE PAN: Kraków, Poland, 2005; pp. 59-72, ISBN 83-89174-04-9.

58. Ślizowski, J.; Kasprzyk, W.; Lankof, L. Właściwości reologiczne iłowców solnych. In Badania Laboratoryjne Zubrów (Iłowców Solnych) dla Oceny Możliwości Składowania Odpadów Promieniotwórczych w Polskich Wysadach Solnych; Ślizowski, K., Ed.; Wydawnictwo IGSMiE PAN: Kraków, Poland, 2005; p. 107, ISBN 83-89174-04-9.

59. Weidinger, P.; Hampel, A.; Blum, W.; Hunsche, U. Creep behaviour of natural rock salt and its description with the composite model. Mater. Sci. Eng. A 1997, 234-236, 646-648. [CrossRef]

60. Hunsche, U.; Hampel, A. Rock salt-The mechanical properties of the host rock material for a radioactive waste repository. Eng. Geol. 1999, 52, 271-291. [CrossRef]

61. Yang, C.; Daemen, J.J.K.; Yin, J.H. Experimental investigation of creep behavior of salt rock. Int. J. Rock Mech. Min. Sci. 1999, 36, 233-242. [CrossRef]

62. Ślizowski, J. Identyfikacja parametrów równania konstytutywnego iłowców solnych. In Badania Laboratoryjne Zubrów (Iłowców Solnych) dla Oceny Możliwości Składowania Odpadów Promieniotwórczych w Polskich Wysadach Solnych; Ślizowski, K., Ed.; Wydawnictwo IGSMiE PAN: Kraków, Poland, 2005; pp. 83-94, ISBN 83-89174-04-9.

63. Cristescu, N.D.; Hunsche, U. A comprehensive constitutive equation for rock salt: Determination and application. In Proceedings of the Mechanical Behavior of Salt: 3rd Conference, Palaiseau, France, 14-16 September 1993; Ecole Polytechnique: Palaiseau, France, 1993; pp. 177-191.

(C) 2020 by the author. Licensee MDPI, Basel, Switzerland. This article is an open access article distributed under the terms and conditions of the Creative Commons Attribution (CC BY) license (http://creativecommons.org/licenses/by/4.0/). 